\title{
Mål, motivation og fokus i undervisningen - med e-portfolio
}

\section{Laila Kjærbæk}

Lektor, ph.d.

Center for Sprog og Læring, Institut for Sprog og Kommunikation, Syddansk Universitet.

Forsker i sprogtilegnelse og underviser indenfor områderne sprogvidenskab og sprogtilegnelse.

\section{Inger-Marie F. Christensen}

\section{Specialkonsulent}

SDU Universitetspædagogik, Syddansk Universitet.

Arbejder med undervisningsudvikling og kompetenceud-

vikling af undervisere i e-læringspædagogik og -værktøjer.
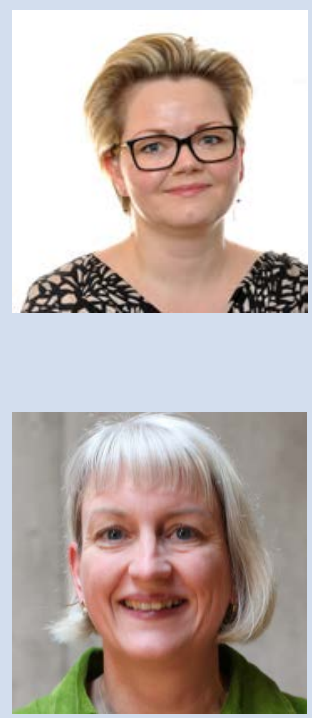


\section{Abstract}

Denne artikel undersøger, hvordan e-portfolio kan bruges til at skabe mål, motivation og fokus i undervisningen på en videregående uddannelse på baggrund af evaluering af et e-portfolioforløb. Antagelsen er, at netop det, at de studerende har et mål med undervisningen, hjælper dem til at bevare det nødvendige fokus undervisningsforløbet igennem, og motiverer dem i deres arbejde - hvilket antages i sidste ende at øge deres læringsudbytte.

Resultaterne af undersøgelsen indikerer, at en e-portfolio kan fungere som den røde tråd i undervisningsforløbet, hvor den kan være med til at skabe det nødvendige overblik over fagets forskellige elementer og tydeliggøre sammenhængen mellem dem. Dette ses som en stærkt motiverende faktor for de studerende, ligesom det virker motiverende for dem, at de kan følge med i medstuderendes arbejde, give/modtage feedback og lade sig inspirere af dette. Resultaterne viser endvidere, at grundig vejledning ift. anvendelse af portfolioværktøjet samt tydelige retningslinjer og krav til arbejdet med portfolioen er nødvendige for et vellykket forløb.

\section{Abstract in English}

On the basis of the evaluation of an e-portfolio course, this article investigates how e-portfolios can be used to create goals, motivation and focus in a study programme in higher education. The presumption is that the fact that the students have specific goals (learning objectives), helps them maintain the necessary focus throughout the study programme and motivates them in their work - which is believed to ultimately enhance their learning outcome.

The results of the study indicate that an e-portfolio can serve as the common thread in the study programme, where it supports the creation of an overview of the different components of the subject and clarifies the link between them. This is seen as a powerful motivating factor for the students; likewise it is motivating for them to be able to follow the work of fellow students, give and receive feedback and be inspired by this. Furthermore, the results show that thorough support regarding the use of the portfolio tool and clear guidelines and requirements for students' work with the portfolio are necessary for success.

\section{Indledning og baggrund}

Førsteårsstuderende på universitetet er optagede af at navigere i det nye læringsmiljø og kortlægge krav og forventninger. Samtidig oplever de, at der er mindre hjælp og vejledning til rådighed, end de har brug for. Der kræves således en høj grad af tilpasning hos den enkelte (Briggs, Clark \& Hall, 2012; Entwistle, 2009; Yorke, 2006). På universitetet forventes de studerende i højere grad selv at planlægge deres tid, prioritere mellem aktiviteter og organisere deres studium. De møder knap så eksplicitte krav 
og kæmper for selv at skabe mening med og se relevansen af kurser og andre studieaktiviteter. Hertil kommer, at nye studerende ofte ser viden som noget, der overføres fra undervisere og bøger til de studerende og kun gradvist opdager, at viden ændres over tid og aktivt konstrueres (Entwistle, 2009; Wingate, 2007).

Der er således store forskelle på de studerendes forståelse af viden og læring samt det at studere på universitetet og undervisernes forventninger (Johannsen, Ulriksen \& Holmegaard, 2013; Wingate, 2007). Universitetsundervisere forventer bl.a. motiverede studerende, der viser interesse for faget og engagerer sig i undervisningen mhp. at forstå fagets forskellige elementer, dvs. en høj grad af indre motivation. Det er dog ikke altid tilfældet i praksis (Means, Jonassen \& Dwyer, 1997). Den indre motivation er imidlertid afgørende, da den hjælper de studerende til at engagere sig $\mathrm{i}$ læreprocesser, der fremmer deres forståelse af fagene. Studerende, der oplever indre motivation er mere tilbøjelige til at anvende en dybdelæringstilgang, specielt hvor deres forståelse af viden har flyttet sig og er blevet mere kompleks (Baeten, Kyndt, Struyven \& Cochy, 2010; Entwistle, 2009). Dybdelæring hænger således sammen med forståelsen af viden som noget, der konstrueres, hvor overfladelæring er tilegnelse af viden (Struyven, Dochy, Janssens \& Gielen, 2006) og nyttig, når den studerende skal lære fagspecifikke fakta (Entwistle, 2009). Yorke (2006) hævder, at studerende anvender en dybdelæringstilgang til de dele af studiet, der ses som essentielle for fremtidigt job mens en overfladelæringstilgang anvendes for dele, der ses som mere perifere. Entwistle (2009) peger på tydelige karrieremål som en drivkraft for den studerende ift. at se relevansen af de fag, de møder, og dermed en faktor, der styrker den indre motivation.

Førsteårsstuderende anvender ofte en overfladelæringstilgang til studierne (Donnison \& Penn-Edwards, 2012), hvor de fokuserer på, hvad man skal kunne til eksamen og ser de forskellige komponenter i et kursus som isolerede dele jf. tabel 1 nedenfor. Dette medvirker til, at de studerende har svært ved at se relevansen af og finde sammenhænge mellem et fags forskellige emner, en uddannelses forskellige fag samt en uddannelses forskellige fag og fremtidigt job. Den manglende oplevelse af relevans er problematisk, da det kan have en negativ effekt på de studerendes motivation og dermed på deres læringsudbytte (Means et al, 1997). Ligeledes er overfladelæring problematisk, da det både er et resultat af - men også med til at skabe - manglende interesse for faget (Entwistle, 2009), og dermed kan overfladelæring sætte gang i en negativ spiral. Hertil kommer, at dybdelæring har vist sig at føre til et læringsudbytte af højere kvalitet end overfladelæring (Baeten et al., 2010; Struyven et al., 2006; Trigwell \& Prosser, 1991). 


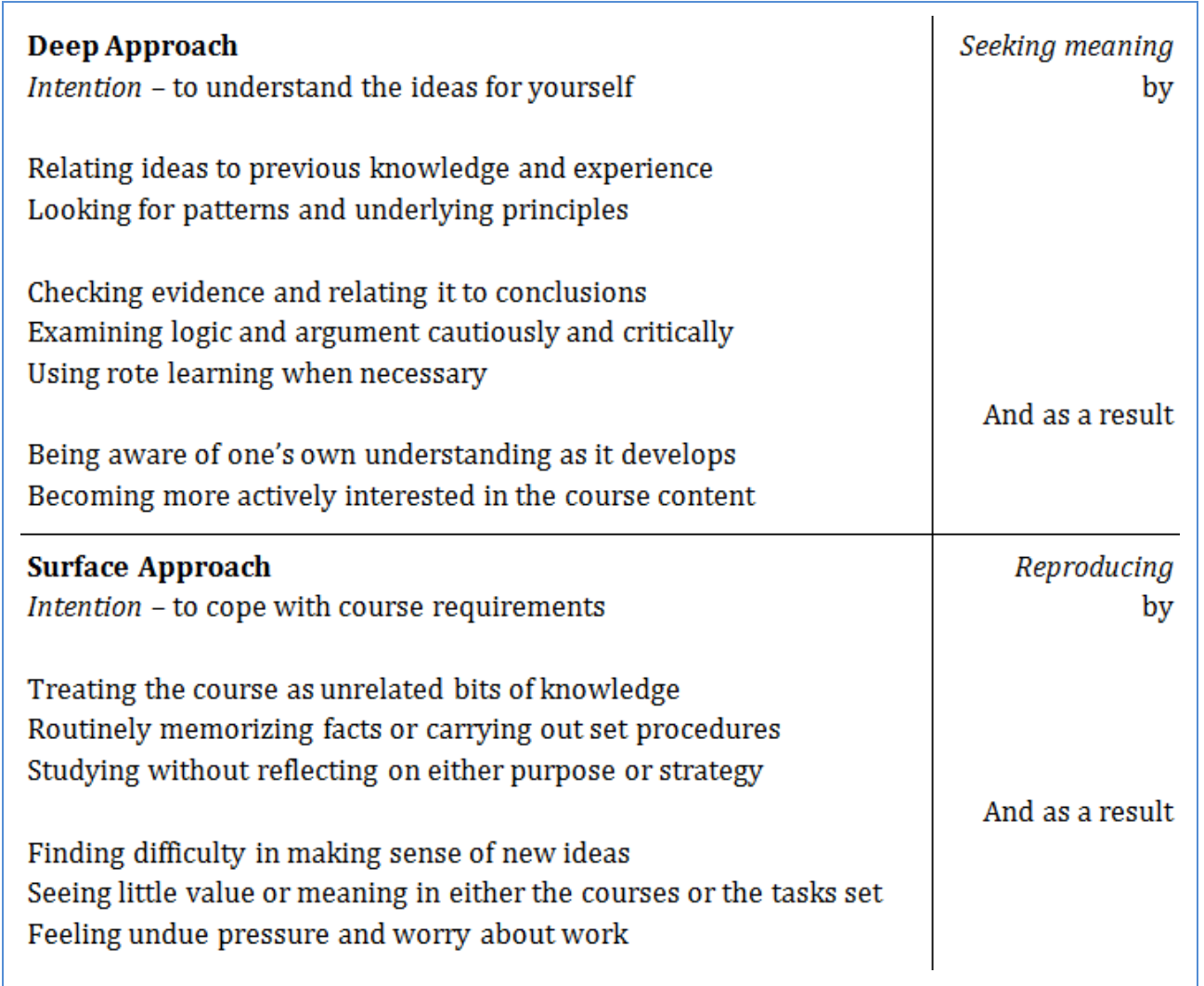

Tabel 1. Karakteristik af dybdelæring og overfladelæring (Entwistle, 2009, s. 36).

Relevans, motivation og dybdelæring er således tæt forbundne elementer, der understøtter førsteårsstuderende i at blive kompetente universitetsstuderende og øger deres læringsudbytte. Studerende har selv et ansvar ift. motivation og interesse for de fag, de møder på deres studium. Imidlertid påvirkes motivation og interesse og dermed tilgang til læring også af den undervisning og udprøvning, de studerende oplever (Baeten et al., 2010; Entwistle, 2009; Struyven et al., 2007).

Denne artikel skriver sig ind i forskningsfelterne førsteårspædagogik og læringstilgange og den overordnede problemstilling er, hvordan undervisning og udprøvning kan tilrettelægges, sådan at de studerende oplever relevans, føler sig motiverede og anvender en dybdelæringstilgang. Mere konkret undersøges, hvordan der kan skabes mål, motivation og fokus i undervisningen ved anvendelse af e-portfolio. Dermed knytter artiklen sig også til anvendelsen af læringsteknologi i universitetsundervisningen, som efterhånden er udbredt men hvor der stadig sættes spørgsmålstegn ved effekten (Price \& Kirkwood, 2013) samt formålet (Selwyn, 2016). Hertil kommer, at der er stor forskel på studerendes digitale kompetencer, hvor nogle stadig er på et basalt niveau (Henderson, Selwyn, Finger \& Aston, 2015). 
Undersøgelser viser, at studerende først og fremmest anvender digitale teknologier, dvs. computere, men også tablets og smartphones samt internet til de logistiske aspekter af deres studier, dvs. planlægning, arkivering og organisering af dokumenter, bibliotekslån, informationssøgning, produktion og aflevering af opgaver. Når det kommer til læring via digitale teknologier involverer det oftest "the passive consumption of knowledge rather than more active practices" (Henderson et al., 2015, s. 317). Endelig ses underviserens kompetencer ift. den konkrete implementering af læringsteknologi som afgørende for succes (Englund, Olofsson \& Price, 2016), og her handler det ikke blot om tekniske færdigheder men også om, hvordan læringsteknologi kan integreres i undervisningen på en inspirerende måde, der fremmer de studerendes læring (Selwyn, 2016). Der er således en række vigtige opmærksomhedspunkter ift. implementering af e-portfolio i universitetsundervisningen.

I denne artikel belyses studerendes oplevelse af brugen af e-portfolio i faget Teoretisk og Anvendt Sprogvidenskab I - Morfologi og Syntaks (TAS I) på 1. semester af Audiologi- og Logopædi-uddannelserne på Syddansk Universitet (SDU), hvor e-portfolio er blevet anvendt med gode erfaringer og justeret ad flere omgange. Formålet er at undersøge, hvilken effekt anvendelsen af e-portfolio har på de studerendes motivation, oplevelse af relevans samt tilgang til læring. På baggrund af erfaringerne fra TAS Iforløbet vil artiklen præsentere en model for integration af e-portfolio, der kan hjælpe de studerende med at skabe relevans og se sammenhænge og dermed understøtte motivation og interesse i universitetsstudiet.

Indledningsvist diskuteres potentialer og problemstillinger knyttet til implementering og anvendelse af portfolio, herunder e-portfoliometoden, dernæst gøres rede for det anvendte undersøgelsesdesign, efterfulgt af en præsentation af TAS I portfolioforløbet. Herefter præsenteres, analyseres og diskuteres undersøgelsens resultater. Artiklen afsluttes med forslag til en model for integration af e-portfolio, der bidrager til at skabe den relevans og sammenhæng, der er så afgørende for de studerendes motivation, interesse og læringstilgang samt en opsummering af undersøgelsens konklusioner.

\section{E-portfolio som redskab til at sikre relevans og sammenhæng}

"En portfolio er i sig selv en tom beholder eller mappe - en metafor. Det er det, man vælger at lægge i den og begrundelserne herfor, der kan forvandle den til et pædagogisk redskab." (Lund, 2008, s. 11)

I denne sammenhæng defineres portfolio som "a purposeful collection of student work that exhibits the student's efforts, progress and achievements 
in one or more areas" (Paulson, Paulson \& Meyer, 1991, s. 60). Portfolioer ses som effektive læringsredskaber, da studerende typisk løbende gennem semestret udarbejder portfolioopgaver i stedet for at lægge den største indsats til slut i semestret op til eksamen (Dysthe \& Engelsen, 2011). Portfoliometoden er netop et alternativ til traditionelle eksamensformer, da den integrerer undervisning og udprøvning og samtidigt aktivt involverer den studerende (Paulson et al., 2003; Smith \& Tillema, 2003).

Portfolio som evalueringsredskab giver desuden mulighed for en bredere vurdering af den studerende (Paulson et al., 1991, s. 63). Fokus skifter fra udprøvning af viden til udprøvning af de studerendes kompetencer og præstationer; samtidig er det med omhyggelig implementering muligt at understøtte de studerendes personlige og faglige udvikling. De studerende involverer sig aktivt og tager ejerskab for egen læring (Popescu-Mitroia, Todorescu \& Greculescu, 2015).

\section{Portfoliotype og -metode}

Den type portfolio, der er i fokus i denne artikel kan bedst beskrives som en "disciplinary course work portfolio", der anvendes som redskab til både læring og udprøvning, og som er tæt knyttet til et specifikt kursus' indhold og læringsmål . Ofte med foruddefinerede krav og feedbackprocesser (Dysthe \& Engelsen, 2011). I Smith og Tillemas (2003) terminologi er der tale om en "training portfolio" (en uddannelsesportfolio), som er:
"a required or mandated exhibit of efforts collected during learning or in a curriculum programme. It highlights the core professional knowledge, skills or competencies a person has acquired and is collected during the time frame of a course as a representative sample of the students' work. Some reflective comments in the training portfolio might explain the selected evidence. This portfolio type often has a fixed format to help the collector provide appropriate evidence."
(Smith \& Tillema, 2003, s. 627)

Imidlertid er det personlige udviklingsperspektiv centralt ift. udfordringen med relevans, det at se sammenhænge mellem uddannelse og fremtidigt job og skabe sig en faglig identitet. Dette gør den personlige udviklingsportfolio relevant. Den personlige udviklingsportfolio er:
"a personal evaluation and reflective account of professional growth during a long-term process. The collection itself is an opportunity to discuss and give value to the activities of the person who is building an identity. The importance of the collection lies in the opportunity for sustained conversation with peers or colleagues about experiences and in refining or 
restructuring one's growth."

(Smith \& Tillema, 2003, s. 627)

Smith \& Tillema (2003) peger på en række væsentlige problemer ift. udarbejdelse af portfolioer. Det kan være svært at beslutte hvor meget tid, man skal investere i en given portfoliotype. Der kan indledningsvist være forvirring og manglende forståelse ift., hvad der kræves. Der kan mangle vejledning og support samt være vanskeligheder ifm. at samle og udvælge det krævede indhold. Især ifm. udarbejdelse af en personlig udviklingsportfolio, dvs. udvælgelse af indhold samt selvevaluering, kræves professionel modenhed og glæde ved akademisk frihed. Smith \& Tillema (2003) har identificeret tre kriterier, der skal imødekommes for at sikre et vellykket portfolioforløb:

- "Clarity": Udarbejdelse af tydelige portfolio-guidelines til den studerende.

- "Feasibility": Gennemførligheden - har den studerende mulighed for rent faktisk at udarbejde det ønskede materiale til portfolioen?

- "Trust": Tillid til udbyttet - kan der træffes relevante følgeslutninger ud fra det materiale, der samles i portfolioen?

\section{E-portfolio - muligheder og udfordringer}

E-portfolio kan spille en afgørende rolle i at løse den konflikt, der eksisterer i dag på universiteterne. På den ene side presses der på for at få studerende hurtigt igennem uddannelsessystemet, og på den anden side presses der på for at sikre høj kvalitet i universitetsuddannelserne. E-portfolioer kan understøtte de studerende i at anvende en dybdelæringstilgang og dermed lykkes som studerende, se relevans og sammenhænge på tværs og blive bevidste om egen udvikling. Det er især e-portfoliopædagogikkens refleksive dimension, der gør sig gældende her:

"reflective e-portfolio pedagogy help students make meaning from specific learning experiences and connections to other experiences, within and beyond the course. Ultimately, students recursively connect their learning to consideration of goals and values, constructing a more intentional and purposeful sense of self."

(Eynon, Gambino, \& Török, 2014, s. 15)

E-portfolioer har endvidere potentiale ift. at øge de studerendes motivation. Dette sker dels via udvælgelse og dels via publicering af eget arbejde i e-portfolien, hvilket er handlinger, som kan give større selvtillid (Smith \& Tillema, 2003; Woodward \& Nanlohy, 2004). Undersøgelser viser dog, at der kan være ulemper forbundet med at anvende e-portfolio. Studerende tilkendegiver, at teknologien kan være frustrerende og tidskrævende, og 
effektiv anvendelse afhænger af den enkelte studerendes IT-færdigheder samt motivation (Smith \& Mills, 2009; Mohamad, Embi \& Nordin, 2016). Dette modsiges dog af Driessen, Muijtjens, Tartwijk \& Vleuten, som angiver følgende fordele ved web-baserede portfolioer holdt op imod papirbaserede: "greater diversity of presentation modalities; greater ease of use; better organisation and structure of content; and enhanced student motivation" (Driessen et al., 2007, s. 1068).

Papirbaserede portfolioer kan give udfordringer ift. mulige typer af indhold, adgang, deling og vurdering. En webbaseret e-portfolio giver mulighed for at skabe, redigere, lagre og organisere multimedieindhold, at tilgå portfolioen fra forskellige lokationer og typer af enheder samt deling af portfolioen med andre og feedback fra disse. Betingelserne er således til stede for interaktion og engagement, som er vigtige parametre ift. et vellykket portfolioforløb (Mohamad et al., 2016).

Der er således belæg for at konstatere, at e-portfolioen rummer en række potentialer, men det er vigtigt ikke at tage for givet, at de studerende har de nødvendige IT-tekniske kompetencer (Lund, 2008). Studerende i dag bruger ofte meget tid online på sociale medier. Imidlertid er det kun få studerende, der har erfaringer med at lære online, og mange er derfor usikre og utrygge, når de skal anvende virtuelle læringsmiljøer, som fx et webbaseret portfolioværktøj. Derfor er teknisk, logistisk, såvel som pædagogisk support nødvendig for at understøtte implementering (Chen, Seilhamer, Bennet \& Bauer, 2015; Johnson et al., 2016). Et velfunderet didaktisk design er afgørende og der skal formuleres retningslinjer og vejledninger til de studerende. Fokus må ikke blot være på introduktion af en ny teknologi men på anvendelsen af e-portfolio som pædagogisk metode (Woodward \& Nanlohy, 2004; Güzeller, 2012; Mohamad et al., 2016).

\section{E-portfolio, modtagere og refleksion}

I forløb, hvor e-portfolioen er en del af udprøvningen, vil studerende ofte se underviseren (bedømmeren) som "key audience", men de bør også opfordres til at se sig selv som "prime audience". Dette er et vigtigt parameter ift. den studerendes personlige udvikling (Woodward \& Nanlohy, 2004). Den sociale dimension, dvs. medstuderende som modtagere, kan ligeledes øge læringsudbyttet. "When students know that peers are looking at and commenting on their e-portfolio, its value as a learning experience is significantly enhanced" (Eynon et al., 2014, s. 15). Det at se sig selv samt medstuderende som modtagere kan fastholde de studerendes opmærksomhed på e-portfolioen som et redskab til understøttelse af læring og personlig udvikling og ikke blot et evalueringsredskab. Her spiller refleksion en central rolle: 
"Reflection lies somewhere around the notion of learning and thinking. We reflect in order to learn something, or we learn as a result of reflecting."

(Moon, 2004, s. 186)

\section{Unders $\varnothing$ gelsesdesign}

Der blev anvendt en mixed-methods tilgang, der kombinerer kvantitative og kvalitative forskningsmetoder i et undersøgelsesdesign, hvor de to metoder komplementerer hinandens styrker (bl.a. ift. bredde og dybde) uden overlappende svagheder. Studiet er designet som 'opfølgende kvalitativ metode i et kvantitativt studie' (Morgan, 1998), hvilket vil sige, at den kvantitative metode er den primære, mens den kvalitative metode er brugt komplementerende. Der er valgt et delvist simultant og delvist sekventielt undersøgelsesdesign, hvor der først blev gennemført en spørgeskemaundersøgelse baseret på både kvantitativ og kvalitativ metode og dernæst en interviewundersøgelse baseret på kvalitativ metode. Der er således tale om metodeintegration (Frederiksen, 2013), hvor resultaterne fra et (delvist) kvantitativt studie blev anvendt til at formulere en interviewguide til et efterfølgende kvalitativt studie. Formålet med det kvantitative studie var at opnå bredde i besvarelserne fra så mange deltagere som muligt, mens formålet med det kvalitative studie var at opnå en dybere og mere nuanceret viden ift. spørgeskemaundersøgelsens resultater. Der er anvendt dataintegration, da informanterne i interviewundersøgelsen er fundet blandt deltagerne i spørgeskemaundersøgelsen samt fortolkningsintegration, hvor data fra interviewene er anvendt til at nuancere data fra spørgeskemaundersøgelsen. Figur 1 illustrerer undersøgelsens fire grundlæggende faser.

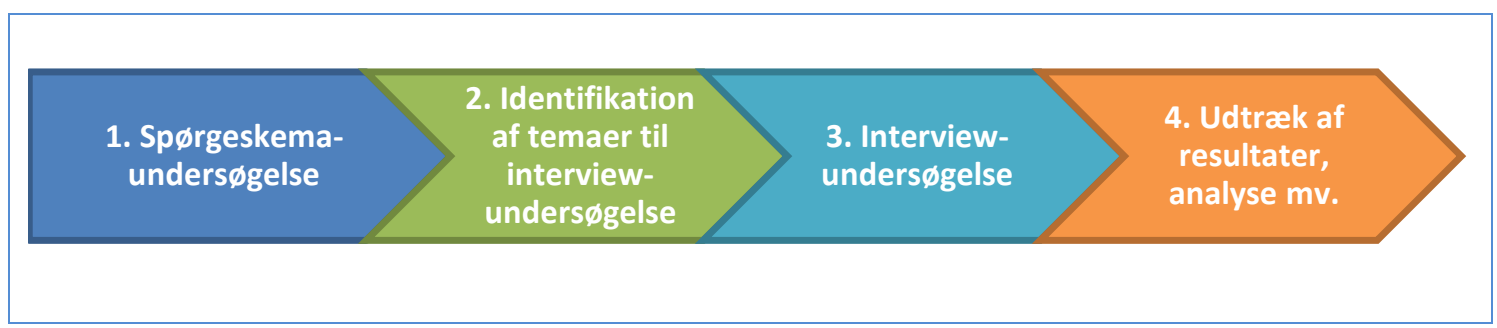

Figur 1. Undersøgelsens fire faser.

\section{1. trin: Spørgeskemaundersøgelse}

Spørgsmålene (se Bilag 1) omhandlede de studerendes egen retrospektive oplevelse af arbejdet med og udbyttet af e-portfolioen centreret omkring mål, motivation og fokus i undervisningen, og der blev spurgt til i hvor høj grad arbejdet med e-portfolioen har medvirket til at:

- den studerende har sat konkrete mål for sin egen læring.

- motivere den studerende i undervisningen.

- gøre den studerendes læring mere fokuseret. 
Der blev endvidere spurgt til i hvor høj grad arbejdet med e-portfolioen har bidraget til at skabe sammenhæng og relevans mellem fagets og uddannelsens forskellige elementer samt mellem uddannelsen og fremtidigt job. Derudover blev den studerende spurgt om eget udbytte af arbejdet med portfolioen, hvad der fungerede godt og mindre godt samt forslag til forbedringer. Spørgeskemaet blev indledt med seks lukkede spørgsmål med faste svarmuligheder, der skulle besvares ved afkrydsning, efterfulgt af seks åbne spørgsmål, der skulle besvares med fri tekst. De faste svarmuligheder bestod af følgende femtrinsskala: 1) I meget høj grad; 2) I høj grad; 3) I nogen grad; 4) I lav grad; og 5) Slet ikke. Efter de første tre lukkede spørgsmål var der mulighed for at uddybe med fri tekst. Spørgeskemaet blev udviklet pba. Johnson \& Christensens (2012) principper.

Spørgeskemaet blev besvaret elektronisk via SurveyXact ifm. den sidste undervisningsgang. Besvarelse af spørgeskemaet skete anonymt. Ud af de 78 studerende, der fulgte TAS I-kurset (fordelt på to hold), besvarede 64 studerende spørgeskemaet. Der er således opnået en svarprocent på $82 \%$ (yderligere 5 studerende besvarede dele af spørgeskemaet).

\section{2. trin: Identifikation af temaer til interviewundersøgelse}

De indkomne besvarelser blev gennemgået med henblik på at identificere temaer, som skulle søges uddybet i interviewundersøgelsen.

\section{3. trin: Interviews}

Den kvalitative interviewundersøgelse blev gennemført ud fra en fænomenologisk tilgang (Kvale \& Brinkmann, 2015). Der blev udviklet en interviewguide (se Bilag 2) på baggrund af de i spørgeskemaundersøgelsen identificerede temaer. Der blev gennemført semistrukturerede interviews med fire studerende (informanterne refereres til som hhv. I1, I2, I3, I4 nedenfor). Informanterne blev udvalgt efter et princip om, at der skulle være én mandlig og én kvindelig studerende fra hvert af de to hold. To blev spurgt og to meldte sig selv. Intervieweren fulgte interviewguiden tæt, dog med mulighed for at stille opklarende og uddybende spørgsmål. Interviewene blev gennemført ansigt-til-ansigt mellem interviewer (underviser) og informant (studerende). Tilstede var også en transkriptør, der transskriberede interviewene ordret på stedet.

4. trin: Udtræk af resultater, analyse mv.

Det endelige dataudtræk fra spørgeskemaundersøgelsen blev foretaget via SurveyXact. Besvarelserne fra de lukkede spørgsmål blev opgjort kvantitativt (se Figur 2-7), mens svarene fra de åbne spørgsmål dels blev behandlet som en tekst, hvor meningen blev fortolket, og dels blev kodet manuelt til kvantitative analyser ( $\mathrm{fx}$ nævnes det 45 gange i spørgeskemaets frie tekst, at e-portfolioen har været medvirkende til at skabe overblik og struktur). 
De transskriberede interviews blev først meningskodet ud fra en begrebsstyret tilgang (Kvale \& Brinkmann, 2015). Artiklens forfattere gennemlæste de kodede transskriptioner uafhængigt af hinanden og dannede sig et overordnet indtryk, hvorefter de foretog en meningskondensering, hvor informanternes meningsenheder sammenfattedes til kortere udsagn i temaer. Herefter blev tematiseringer diskuteret, udsagn, der viste samme og/eller forskellige holdninger til et fænomen, blev optalt, og den endelige sammenskrivning og analyse blev udført (Kvale \& Brinkmann, 2015).

\section{Metodekritik}

Det er en styrke, at undersøgelsen benytter sig af komplementerende kvantitative og kvalitative metoder, da det optimerer de stærke sider ved interview og spørgeskemaer, bl.a. ved at spørgeskemaundersøgelsen undersøgte generaliteten af synspunkter, mens interviewene bidrog med konkrete og nuancerede eksempler til understøttelse af påstandene (Kvale \& Brinkmann, 2015).

Når man læser resultaterne af de lukkede spørgsmål i spørgeskemaundersøgelsen, må man være opmærksom på, at informanterne har svaret ud fra hvilken værdi, de selv har tillagt kategorierne i 5 -trinsskalaen. Hver enkelt informant har således ikke nødvendigvis tillagt de enkelte kategorier den samme værdi, hvilket kan udgøre en fejlkilde i undersøgelsen.

Der vil som oftest være et asymmetrisk magtforhold mellem interviewer og den interviewede, og i denne undersøgelse kan denne asymmetri have været forstærket af, at intervieweren også var underviser i faget. Informanterne kan have svaret mere positivt, end de ellers ville have gjort af frygt for at støde underviseren. Underviserens indgående kendskab til hele portfolioforløbet blev dog tillagt så stor vigtighed, at det blev besluttet at fastholde denne som interviewer. I et fors $\emptyset \mathrm{g}$ på at mindske skævvridningen, tydeliggjorde intervieweren i begyndelsen af hvert interview vigtigheden af, at informanten uden forbehold gav udtryk for sin egen oplevelse uden hensyntagen til underviseren, da det netop var i underviserens egen interesse at få en så objektiv evaluering af e-portfolioforløbet som muligt, med henblik på enten at gøre lignende e-portfolioforløb endnu bedre i fremtiden eller stoppe brugen af e-portfolio, hvis undersøgelsens resultater pegede i den retning.

Det forholdsvist lille antal informanter i den kvalitative interviewundersøgelse skal ses i lyset af, at den fungerede som supplement til den primære kvantitative undersøgelse med 64 informanter. Det var således et bevidst valg kun at inddrage fire informanter, da det gav mulighed for en mere dybdegående unders $\emptyset$ gelse. Det er muligt at sige interessante ting ud fra en analyse af nogle få tilfælde, selvom man ikke nødvendigvis vil kunne generalisere til større populationer (Kvale \& Brinkmann, 2015). 


\section{Portfolio som lærings-, udviklings- og evalueringsredskab i TAS I}

Beslutningen om at indføre e-portfolio i TAS I blev foretaget på mikroniveau, dvs. at det var underviserens beslutning (Dysthe \& Engelsen, 2011), men den blev truffet i lyset af det bærende princip for uddannelse på SDU på makro-niveau, nemlig aktiverende undervisning og aktiv læring. Eportfolio blev indført som lærings-, -udviklings- og evalueringsredskab for at involvere de studerende aktivt i fortolkning af læringsmålene samt i egen læring og give dem mulighed for løbende at samle og skabe overblik over opgaver, noter, refleksioner m.m. De studerende arbejdede semestret igennem med en personlig e-portfolio, der skulle indeholde specifikke elementer (beskrevet nedenfor), som havde til hensigt at: 1) øge de studerendes viden om fagets relevans; 2 ) skabe sammenhæng mellem fagets forskellige emner, mellem faget og de øvrige fag på uddannelsen samt mellem faget og fremtidigt job; 3) støtte de studerende i at bevare fokus i deres arbejde semestret igennem; og 4) øge de studerendes motivation og interesse for at arbejde med faget.

Udover de obligatoriske elementer, stod det de studerende frit for at lægge yderligere indhold i e-portfolioen for at dokumentere deres læringsudbytte og udvikling. TAS I-portfolioen er i Smith \& Tillemas (2003) terminologi således dels en uddannelsesportfolio (dvs. en obligatorisk undervisningsog evalueringskomponent) og dels en personlig udviklingsportfolio (dvs. udgangspunkt for arbejdet med at se relevansen af og skabe sammenhæng mellem fagets og uddannelsens forskellige elementer i relation til fremtidigt job og dermed arbejde hen imod en faglig identitet).

For at tydeliggøre formål og krav (clarity) med TAS I-portfolioen blev der dels lavet en skabelon i Blackbaords portfolioværktøj, som de studerende skulle vælge, når de oprettede portfolioen, og dels blev der udarbejdet konkrete instrukser til de studerende (se Bilag 3; se eksempler på portfolioer i Bilag 4).

For at bestå kurset skulle de studerende bl.a. være i stand til at udføre morfologiske og syntaktiske analyser. Underviseren lagde dog megen vægt på, at de studerende ikke blot blev vurderet på, om analyserne var lavet "korrekt" eller "ikke-korrekt". Det handlede i lige så høj grad om deres argumentation og tanker bag, og de studerende blev dermed i høj grad vurderet på deres indsats, faglige udvikling og forståelse af pensum. Dette valg blev truffet i erkendelse af, at de studerende befandt sig midt i et læringsforløb, hvor der skulle være plads til udforskning, afprøvning og fejltagelser, der kunne føre faglig udvikling med sig.

TAS I-portfolioen indeholdt følgende elementer, der hver udgjorde en side i skabelonen: 
1) Portræt

2) Mål

3) Begreber

4) Morfologisk Analyse

5) Syntaktisk Analyse

6) Sprogblomster

På siden Portræt skulle de studerende udarbejde et fagligt visitkort. Formålet var at få de studerende til at reflektere over og begynde at skabe deres egen faglige profil. Under Mål skulle de studerende arbejde med målene for faget og sætte sig grundigt ind i studieordning, fagbeskrivelse og undervisningsplan samt overveje fagets relevans for resten af studiet og fremtidigt job. Derudover skulle de reflektere over, hvad de personligt ønskede at få ud af undervisningen, samt hvad de anså som deres styrker og svagheder. Dette var tænkt som en motivationsfaktor, som hjælp til at bevare fokus i undervisningen og som understøttelse af en dybdelæringstilgang.

På de øvrige sider i portfolioen skulle de studerende uploade individuelle, faglige opgaver, hvoraf nogle inkluderede peer-feedback, andre underviserfeedback. Opgaverne havde til formål at øge de studerendes læringsudbytte og hjælpe dem til at forstå stoffet, opnå dyb, såvel som bred viden, træne formulerings- og analysefærdigheder, træne evnen til at give og modtage feedback samt at øge de studerendes opmærksomhed på sprogbrug i praksis for at gøre undervisningen mere vedkommende og relevant. Se bilag 5 for en detaljeret gennemgang af indhold og intentioner på de enkelte sider i portfolioen.

De studerende skulle dele deres portfolio med underviseren og medlemmerne af deres studiegruppe. I TAS I-portfolioforløbet var underviseren således modtager af de studerendes e-portfolioer, hvad angik evalueringsaspektet og e-portfolioens funktion som uddannelsesportfolio. Der var løbende deadlines på aflevering af opgaver i portfolioen, og underviseren vurderede løbende de enkelte opgaver til Godkendt/lkke-Godkendt. Ved semestrets afslutning foretog underviser en samlet vurdering af, hvorvidt den studerende havde bestået faget eller ej, bl.a. på baggrund af den studerendes e-portfolio. Eksamensbestemmelserne for faget er undervisningsdeltagelse (80 \%) samt aflevering af et antal hjemmeopgaver, der skal vurderes til bestået, jf. Studieordningen for BA i Audiologi og BA i Logopædi.

Medstuderende var imidlertid også en central modtager af e-portfolioen, da denne løbende skulle deles med medlemmerne af studiegruppen. Ifm. én opgave skulle der afgives peer-feedback, og semestret og e-portfolioforløbet blev sluttet af med, at de studerende præsenterede deres e-portfolio for hinanden i studiegrupperne, hvor de fortalte om hvert enkelt element 
og bl.a. kom ind på, hvordan de havde løst opgaverne, og hvad de havde fået ud af det. De skulle i den forbindelse også præsentere deres portræt og mål samt reflektere over, om de havde nået disse mål og havde udviklet sig i løbet af kurset, dvs. "a metacognitive reflection on the student's learning and development over a period of time" (Yancey, 1998 her citeret fra Dysthe \& Engelsen, 2011, s. 75). Intentionen var endvidere, at de studerende så sig selv som modtagere og løbende ville reflektere over og tage stilling til, hvad de kunne lægge i e-portfolioen for at dokumentere og fastholde eget læringsudbytte.

I TAS I-forløbet blev der lagt vægt på at vælge et e-portfolio-system, der var let tilgængeligt for de studerende (der var fokus på at undgå forskellige systemer og logins), som kunne opfylde kravene, og som de studerende kunne tage ejerskab for. Det var bl.a. vigtigt, at portfolioværktøjet kunne understøtte de studerendes arbejde med stoffet ud fra flere forskellige modaliteter, hvilket ville give god mulighed for at tilpasse opgaver til det stof og de færdigheder, der skulle læres. Det var samtidig håbet, at brugen af forskellige typer multimedieindhold ville bidrage til, at de studerende fandt arbejdet med faget mere varieret, og dermed mere interessant. Det blev endvidere set som en fordel, at den studerende kunne samle alt sit arbejde (noter, øvelser, afleveringer osv.) ét sted, nemlig i e-portfolioen. Woodward \& Nanlohy fremhæver netop, at e-portfolioen har den unikke egenskab, at den fungerer som et "repository" - et opbevaringssted for den studerendes arbejde - som kan give "added depth and understanding to learning through the portfolio process" (Woodward \& Nanlohy, 2004, s. 230).

På SDU anvendes Blackboard som e-læringsplatform og her oprettes alle kurser før semesterstart. Derudover indeholder e-læringsplatformen et portfolioværktøj, der giver mulighed for at arbejde med multimedieindhold og indeholder en feedback funktion. Her kan alle brugere oprette portfolioer og dele disse med andre brugere i Blackboard. Det blev set som en fordel at anvende Blackboards e-portfolioværktøj, da de studerende allerede havde login og skulle bruge platformen ifm. deres øvrige kurser.

\section{Analyse og diskussion}

Nedenfor præsenteres, analyseres og diskuteres resultaterne af spørgeskema- og interviewundersøgelsen.

De studerende i interviewundersøgelsen giver alle udtryk for, at de opfatter en e-portfolio som et sted, hvor de kan samle og fremvise deres arbejde. De siger samstemmende, at e-portfolioen ikke er noget i sig selv - det handler om de opgaver, som de skal arbejde med i forbindelse med e-portfolioen. 
Mange studerende nævner i spørgeskemaundersøgelsen, at tekniske udfordringer, herunder teknisk utryghed, ikke intuitivt system og uigennemskuelig opbygning, har haft en negativ indvirkning på deres portfolioarbejde. Især deling af portfolioen volder problemer, da det er et snapshot, man deler, når man anvender Blackboards portfolioværktøj - dvs. et øjebliksbillede af portfolioen. Dette skal slettes og et nyt snapshot deles, når der er foretaget ændringer, hvilket har givet anledning til frustrationer, fordi studerende troede, at de havde delt portfolioen, hvor det senere viste sig ikke at være tilfældet. I interviewundersøgelsen lægger informanterne ligeledes vægt på tekniske udfordringer (mange museklik, besværligt at søge brugere frem ifm. deling m.m.) som en begrænsende faktor, men de oplevede det som en stor fordel, at portfolioværktøjet var integreret i samme platform som de øvrige kursusrum og ville ikke vælge et andet værktøj. I2 oplevede, at det fungerede godt med den udleverede guide, I3 nævner, at portfolioværktøjet med fordel kunne forenkles - også layoutmæssigt, mens I4 fandt det så vanskeligt, at han savnede et decideret kursus i brugen af Blackboard.

De fire informanters e-portfolioer indeholdt udelukkende skrevet tekst og enkelte billeder. De har ikke tænkt det som en mulighed at benytte andre multimedietyper, da de gik ud fra det skulle være på skrift som i gymnasiet. De er dog alle begejstrede for idéen om at inddrage andre multimedietyper og foreslår, at underviser fremover laver mindst én opgave, hvor det er obligatorisk at producere fx lyd eller video, for på den måde at få de studerendes øjne op for muligheden. I2 foreslår endvidere, at underviseren får nogle af de mere engagerede studerende til at lægge forskellige typer multimedieindhold på deres e-portfolioer for derigennem at motivere andre studerende til at gøre det samme. Han foreslår samtidig, at de studerende deler deres e-portfolio med hele holdet, da det kan virke inspirerende, og de studerende vil kunne dele fagligt interessante og sjove videoer, artikler osv. Som konkret opgave foreslås det bl.a., at studerende laver en videooptagelse, hvor de fx udfører en syntaktisk analyse på tavlen. Videoen kunne vises i undervisningen og efterfølgende lægges i e-portfolioen.

\section{At arbejde med en e-portfolio}

De studerende i TAS I-forløbet har meget forskellige oplevelser af og tilgange til arbejdet med e-portfolioen. Figur 2 viser i hvor høj grad de studerende i spørgeskemaundersøgelsen har oplevet, at arbejdet med e-portfolioen har medvirket til at motivere dem i undervisningen. Tilsammen har $66 \%$ svaret, at de enten i meget høj grad, i høj grad eller i nogen grad har oplevet, at e-portfolioen har motiveret dem i undervisningen, mens $33 \%$ har svaret enten $i$ lav grad eller slet ikke. 


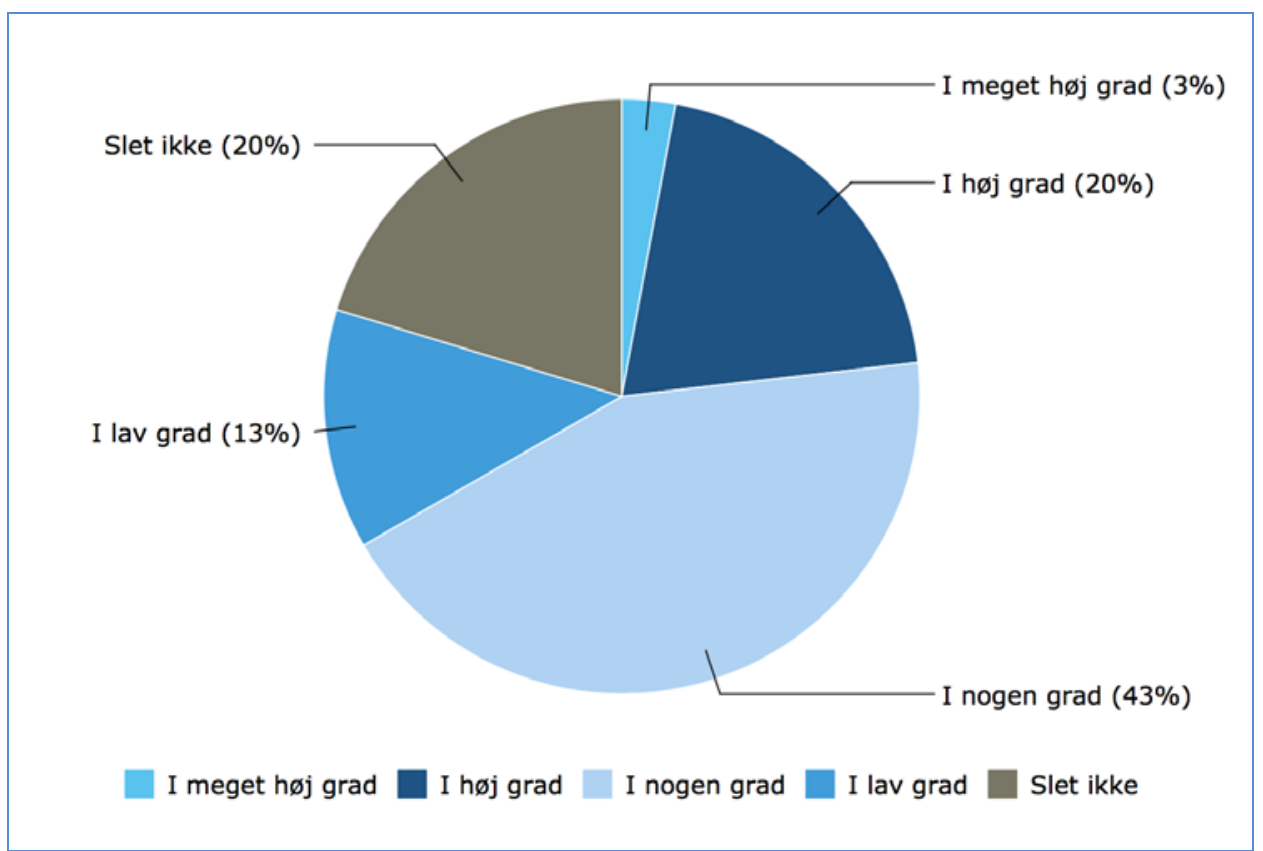

Figur 2. I hvor høj grad har arbejdet med e-portfolioen medvirket til at motivere dig i undervisningen?

I1 fortæller, at hun var meget engageret i og brugte meget tid på e-portfolioarbejdet gennem hele semestret og løbende tog stilling til, hvad hun skulle/ville lægge i portfolioen. Hun gjorde det både for sin egen skyld, da det gav et godt overblik over semestrets arbejde, men hun oplevede det også som en motiverende faktor, at e-portfolioen skulle deles med underviser og studiegruppe. Dette bakkes op af de tre øvrige informanter. Endvidere fandt hun det motiverende, at e-portfolioen talte med i bedømmelsen. Hun gav dog samtidig udtryk for, at hun ville have været endnu mere engageret, hvis e-portfolioen i endnu højere grad var blevet inddraget i undervisning og hjemmeopgaver. Dette støttes af I4, der foreslår, at det imødekommes ved, at der laves flere men mindre portfolioopgaver semestret igennem. Informanterne er endvidere enige om, at det havde været en større motivationsfaktor, hvis e-portfolioen skulle deles med hele holdet. I2 begrunder det bl.a. med, at man på holdet påvirker hinanden og hinandens arbejde: "Det kunne man se i wikien, når først én begyndte at skrive, kom de andre hurtigt efter det", mens I3 begrunder det med, at man ville kunne spore sig ind på, om man gør det rigtige ved at se, hvad andre har gjort. Hun fandt det samtidig inspirerende og lærerigt at læse, hvad andre havde skrevet, samt at give feedback.

To af informanterne så e-portfolioen som noget sekundært, den ene fordi han mest brugte e-portfolioen i begyndelsen af semestret, og derefter blev den noget sekundært, og den anden fordi der gik lang tid, før han opdagede, at portfolioen også var til ham selv. 


\section{Sætte mål for egen læring}

Figur 3 viser, i hvor høj grad de studerende ifølge spørgeskemaundersøgelsen har oplevet, at arbejdet med e-portfolioen har medvirket til, at de har sat konkrete mål for deres egen læring. Tilsammen har $77 \%$ svaret, at de oplever, at e-portfolioen enten i meget høj grad, i høj grad eller $i$ nogen grad har medvirket til, at de har sat sig mål for deres egen læring. Kun $23 \%$ har svaret i lav grad eller slet ikke.

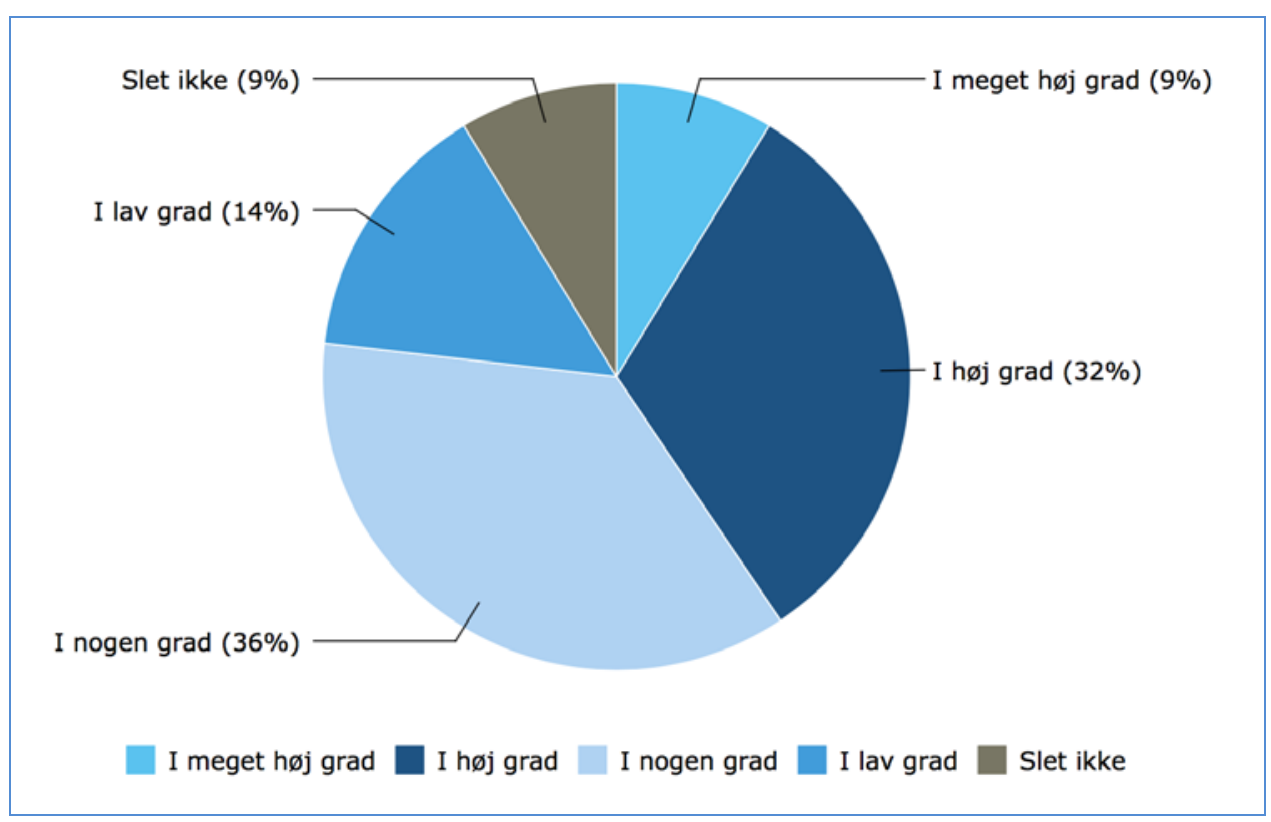

Figur 3. I hvor høj grad har arbejdet med e-portfolioen medvirket til, at du har sat konkrete mål for din egen læring?

En af de studerende uddyber: "Jeg fik sat mig nogle mål, som har kunne[t] guide mig igennem TAS I, hvis jeg har følt, at noget var svært, har jeg kunne[t] holde mig selv [til] ilden ved at læse mine mål og genfinde motivationen". To af informanterne i interviewundersøgelsen nævner, at især opgaverne om portræt og mål virkede motiverende. Det resulterede i, at de, før de for alvor gik i gang med faget, vidste, hvad de ville have ud af det både personligt og fagligt

\section{Fokus}

Figur 4 viser i hvor høj grad de studerende oplever, at arbejdet med eportfolioen har gjort deres læring mere fokuseret. Tilsammen har $68 \%$ svaret, at de enten $i$ meget høj grad, i høj grad eller $i$ nogen grad oplever, at arbejdet med e-portfolioen har medvirket til at gøre deres læring mere fokuseret, mens $32 \%$ enten har svaret $i$ lav grad eller slet ikke. 


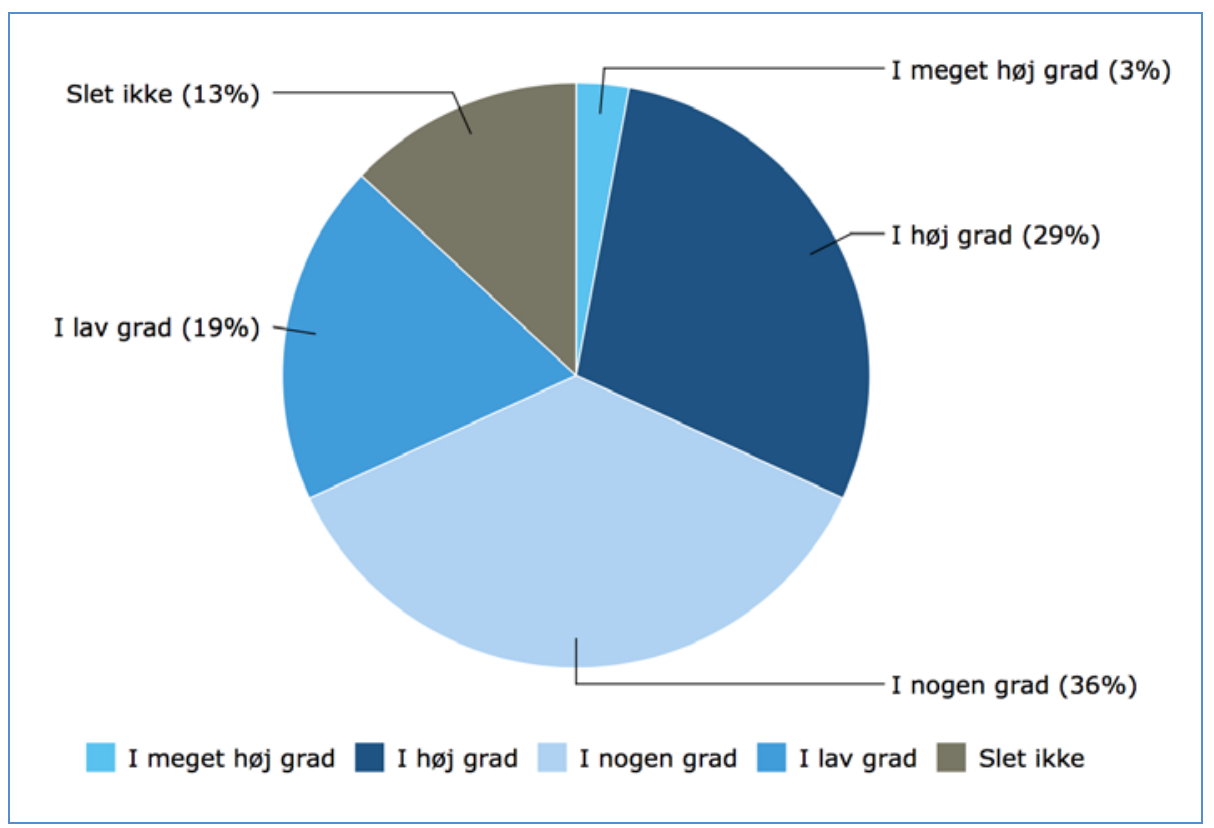

Figur 4. I hvor høj grad har arbejdet med e-portfolioen medvirket til at gøre din læring mere fokuseret?

En studerende uddyber at e-portfolioen har: "Været med til at overskueliggøre læsestoffet og skabe fokus", en anden skriver: "Mine mål fik mig til at fokusere på hvad jeg skal opnå igennem forløbet, altså hvad jeg skal kunne, samt at se hvilke svagheder jeg har", mens en tredje fortæller: "Jeg blev fokuseret på fagets mål og mine egne kompetencer".

\section{Sammenhæng og overblik - den røde tråd}

Figur 5 viser i hvor høj grad de studerende oplever, at e-portfolioen har bidraget til at skabe sammenhæng mellem fagets forskellige elementer. Tilsammen har $85 \%$ af de studerende givet udtryk for, at de enten i meget høj grad, $i$ høj grad eller i nogen grad har oplevet, at arbejdet med e-portfolioen har bidraget til at skabe sammenhæng mellem fagets forskellige elementer, mens kun $15 \%$ har svaret enten i lav grad eller slet ikke. 


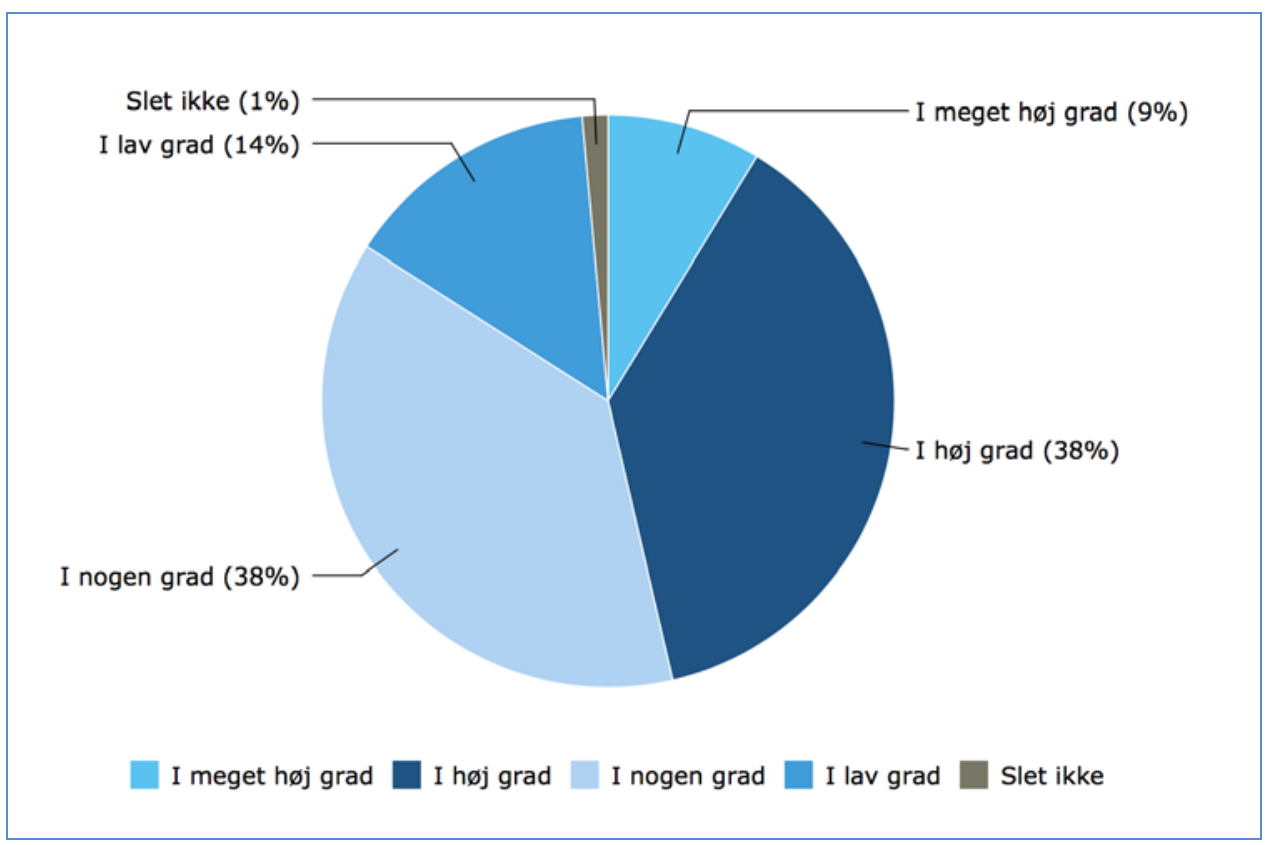

Figur 5. I hvor høj grad har arbejdet med e-portfolioen bidraget til at skabe sammenhæng mellem fagets (TAS I) forskellige elementer?

I spørgeskemaundersøgelsens løbende tekst nævnes det 45 gange, at eportfolioen har været medvirkende til at skabe overblik og struktur, fordi alle opgaver m.m. har været samlet ét sted - det har givet en rød tråd i forløbet. En studerende skriver "[...] det har været et godt redskab i undervisningen til fordybelse og struktur af de løbende opgaver [...]", mens en anden fortæller: "Det giver en fin kontinuitet og sammenhæng mellem opgaverne". Dette nævnes også adskillige gange i interviewene med alle fire informanter. I2 fortalte, at e-portfolioen hjalp ham i den sidste del af semestret, hvor der blev arbejdet med større opgaver, og hvor der var fokus på sammenhænge mellem fagets forskellige elementer. Selvom han havde separate noter, var det e-portfolioen, han støttede sig til ifm. den sidste skriftlige afleveringsopgave i faget.

I2 lægger vægt på vigtigheden af, at indholdet lægges åbent ind i e-portfolioen og ikke som uploadede filer, der skal klikkes på, før indholdet ses. Hvis alt lægges åbent ind i e-portfolioen, er det hurtigt og nemt at scrolle igennem indholdet, det giver overblik, og man kan se sammenhængen. Han mener, at det automatisk vil føre til, at flere vil bruge e-portfolioen aktivt, og at flere vil give feedback til hinanden, hvilket vil højne kvaliteten af eportfolioarbejdet.

Med e-portfolioen blev relevansen af, sammenhængen mellem og overblikket over fagets forskellige dele tydeligere, fortæller informanterne. I3 fortæller, at hun ikke forstod meningen med faget før til sidst, da hun så alle tingene samlet på ét sted. Hun anbefaler, at underviser opfordrer de studerende til at lægge flere øveopgaver i e-portfolioen - en ting til hver del af fagets pensum. På den måde, kan de studerende løbende se, at de udvikler 
sig. I4 synes, at det er godt at have noget at se tilbage på og at have muligheden for at drage paralleller mellem det, han har arbejdet med før, og det, han laver nu.

\section{Sammenhæeng mellem fag}

Figur 6 viser i hvor høj grad de studerende oplever, at arbejdet med e-portfolioen har bidraget til at skabe sammenhæng mellem TAS I og de andre fag på uddannelsen. Tilsammen angiver $30 \%$ af de studerende, at de enten $i$ meget høj grad, i høj grad eller i nogen grad oplever, at arbejdet med e-portfolioen har bidraget til at skabe sammenhæng mellem TAS I og de andre fag på uddannelsen, mens de resterende $69 \%$ angiver i lav grad eller slet ikke.

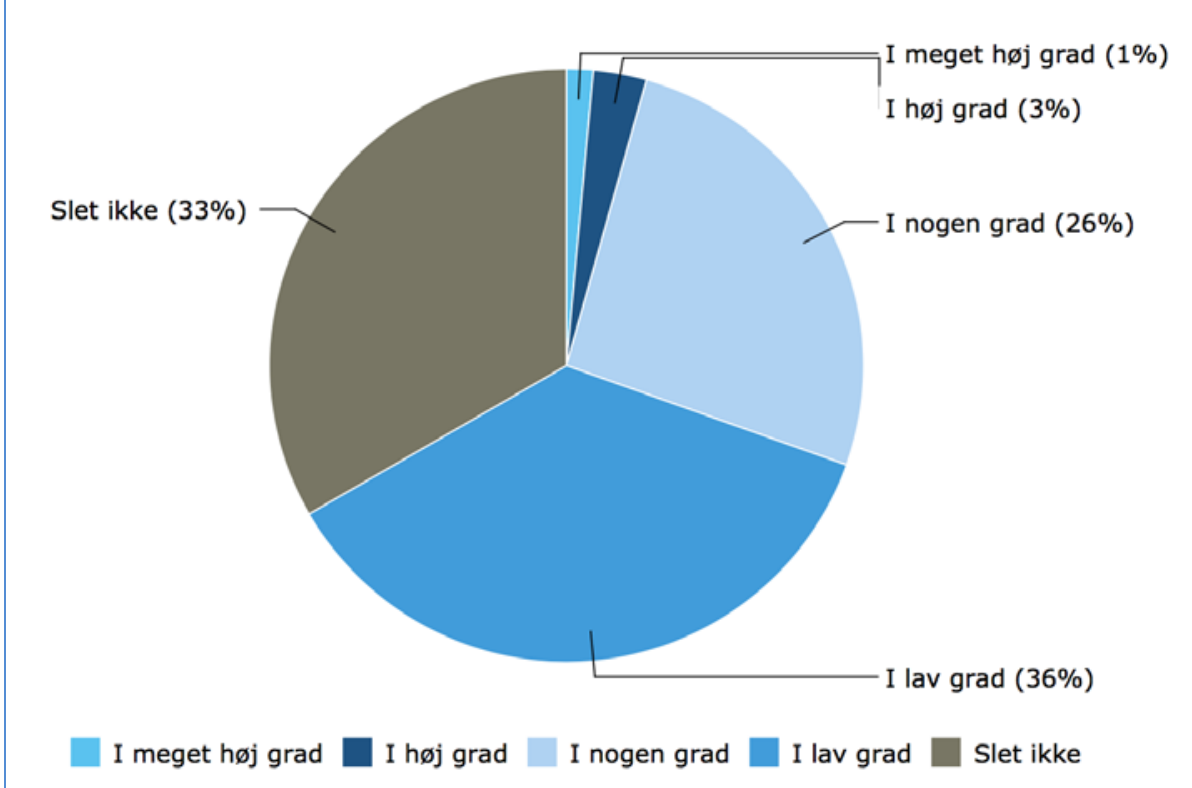

Figur 6. I hvor høj grad har arbejdet med e-portfolioen bidraget til at skabe sammenhæng mellem TAS I og de andre fag på uddannelsen?

Ifølge spørgeskemaundersøgelsen oplever størstedelen af de studerende således ikke, at e-portfolioen i nævneværdig grad har bidraget til at skabe sammenhæng mellem TAS I og de øvrige fag på uddannelsen. Der er dog flere, der nævner, at de kunne have ønsket sig, at der også blev arbejdet med e-portfolio i andre fag. Disse to synspunkter bakkes op at alle fire informanter fra interviewene. I3 nævner, at det vil give en bedre sammenhæng, at man arbejder på samme måde. I4 foreslår, at man laver én stor eportfolio, der indeholder flere fag, da det også kunne muliggøre tværfagligt arbejde.

Det nævnes også, at de studerende kan lave deres egen e-portfolio og evt. dele den med deres studiegruppe - e-portfolioarbejdet behøver netop ikke at være underviserinitieret. I1 siger bl.a. "ikke fordi jeg ikke kan gøre ting selv, eller fordi jeg ikke er motiveret for det, men man skal vænne sig til 
tanken om, at man går på universitetet, man gør det for sig selv, sin egen læring ... man skal have den tankegang ind over portfolioen også".

Det er vigtigt, at underviser tydeliggør, hvad man må og ikke må i e-portfolioen. I1 giver udtryk for, at det er mere lærerigt (og sjovere!), hvis man må være kreativ, eksperimentere og udvikle e-portfolioen på sin egen måde. Endvidere synes han, at det er godt med et forum, hvor man kan kommentere på hinandens ting, da det er rart at få feedback på de ting, man laver og hvor man kunne stille spørgsmål til hinanden.

\section{Sammenhæng med fremtidigt job}

Figur 7 viser i hvor høj grad de studerende oplever, at arbejdet med portfolioen har bidraget til at skabe sammenhæng mellem TAS I og det arbejde, de studerende skal ud og varetage efter endt uddannelse. Tilsammen angiver $58 \%$ af de studerende, at de oplever, at arbejdet med e-portfolioen enten $i$ meget høj grad, i høj grad eller i nogen grad har bidraget til at skabe sammenhæng mellem TAS I og det arbejde, som de skal ud og varetage efter endt uddannelse, mens $42 \%$ enten svarer $i$ lav grad eller slet ikke.

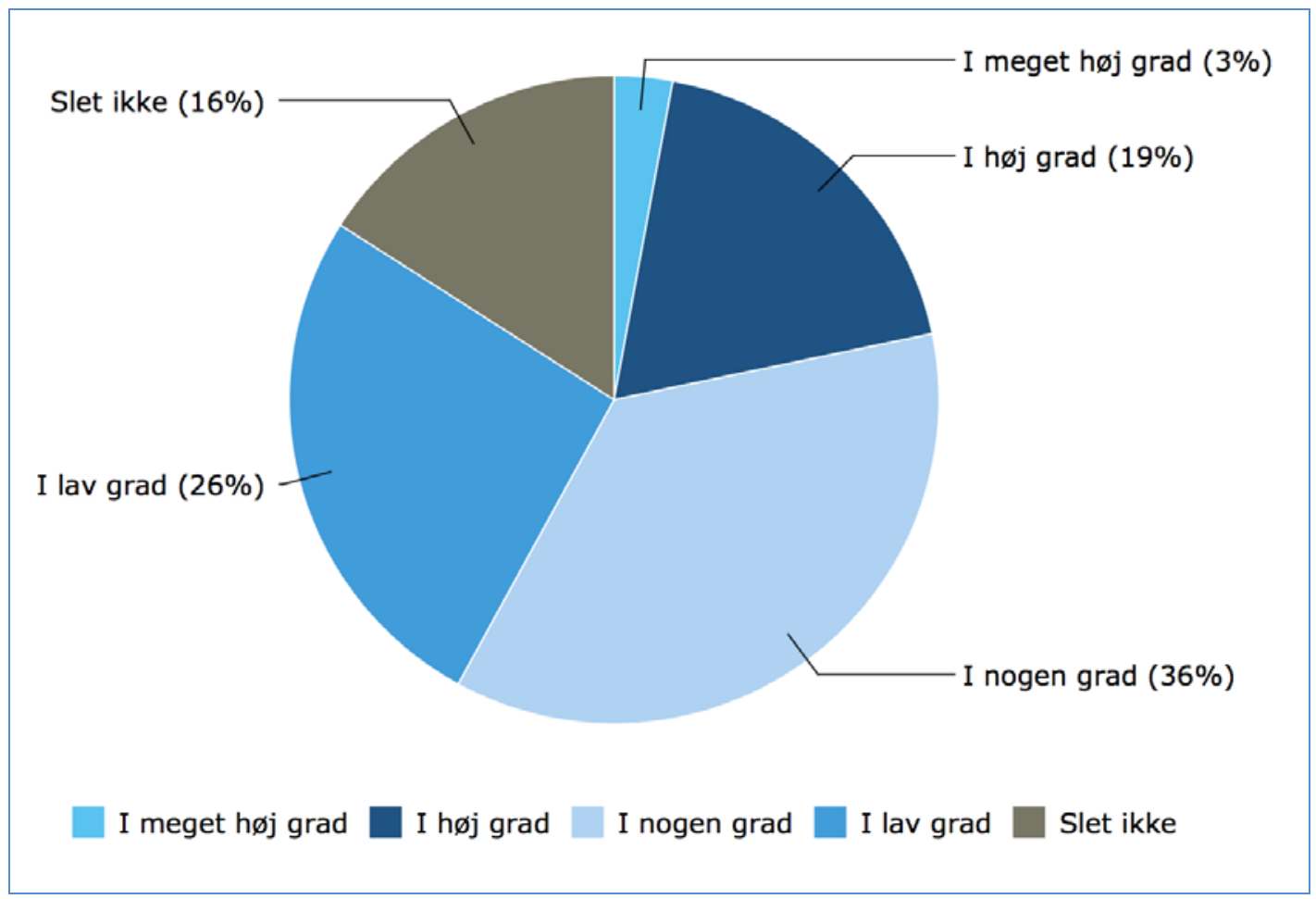

Figur 7. I hvor høj grad har arbejde med e-portfolioen bidraget til at skabe sammenhæng mellem TAS I og det arbejde, som du skal ud og varetage efter endt uddannelse?

Ifølge spørgeskemaundersøgelsen er de studerende meget delte i forhold til dette spørgsmål, og det samme er informanterne fra interviewundersøgelsen. I1 fortalte: "Via den her e-portfolio øver man sig i at skabe sådan en profil. De her opgaver har jeg skrevet, det her arbejde har jeg lavet, det 
er godt at øve sig på nu. Det kunne godt gøres endnu mere [...] det er en måde, hvor man måske også mere kan begynde at finde ud af, ok hvad er det, jeg vil fordybe mig i, hvad for nogle emner [...] hvad er det der interesserer mig meget?" I2 oplevede kun i mindre grad, at e-portfolioen bidrog til at skabe sammenhæng mellem TAS I og fremtidigt job. Han mener, at det ville have understøttet sammenhængen, hvis man havde arbejdet med mål og portræt i alle fag. I3 oplevede at arbejdet med e-portfolioen har sat mange relevante tanker i gang. I4 var den af informanterne for hvem eportfolioarbejdet havde bidraget mest til at skabe sammenhæng mellem TAS I og hans fremtidige job. Han begrundede sit svar: "Ja, det synes jeg, fordi underviser bad os om i starten at skrive om, hvorfor det var vi syntes TAS I var vigtigt. Fordi vi var nødt til at reflektere til sidst, hvad vi havde fået ud af faget og havde ændret holdning til, hvorfor vi havde det fag. Det at skulle overveje det igen og kigge på langt sigt ikke bare et overbliksbillede: har du faktisk udviklet det, du følte for forløbet? Til sidst syntes jeg faktisk at TAS I havde sin berettigelse, også selvom jeg bare skal ud og nørkle med noget akustik".

Ifølge interviewundersøgelsen ser de studerende primært underviseren som målgruppe for e-portfolioen og i nogen grad også de øvrige medlemmer af studiegruppen, som de blev bedt om at dele e-portfolioen med. Imidlertid er der også nogen erkendelse af, at den studerende selv udgør en del af målgruppen. I1 nævner endvidere muligheden for at vise e-portfolioen til fremtidige arbejdsgivere. Mange studerende giver udtryk for, at de i begyndelsen ikke kunne se meningen med e-portfolioen, men sidst i semestret gav det hele mening. Det var altså ofte først til slut i kurset, at de kunne se og forstå, hvad portfolioen kunne tilbyde (feasibility).

\section{Fra underviserens perspektiv}

Arbejdet med e-portfolioen er en god måde at integrere undervisning og udprøvning, som også angivet af Paulson et al. (1991), Smith \& Tillema (2003) og Woodward \& Nanlohy (2004). Der er dog meget arbejde forbundet med et e-portfolioforløb, bl.a. fordi det kan være tidskrævende at udarbejde en god teknisk manual samt tydelige guidelines og meningsfulde opgaver til portfolioarbejdet. Det kræver desuden megen tid og mange museklik, når underviser skal læse, bedømme og kommentere alle portfolioerne - især på hold med mange studerende.

Underviser kunne kun give feedback i løbende tekst via en dedikeret kommentarside i den enkelte e-portfolio, men havde ikke mulighed for at skrive kommentarer til de enkelte sider eller direkte i de studerendes uploadede filer. Dette gav mindre gode muligheder for individuel, direkte og konkret feedback.

De studerende havde problemer med at forstå teknikken og opnå de nødvendige tekniske færdigheder. Dog skyldes dette formodentligt ikke 
manglende support eller guidelines, men for nogle studerendes vedkommende, at de ikke havde læst og fulgt den vejledning, der var tilgængelig. Hertil kommer, at der reelt var problemer med portfoliosystemet, hvor studerende fx ikke kunne dele deres portfolio eller redigere i den efter at have uploadet en fil med specialtegn i filnavnet.

Det er undervisers oplevelse, at e-portfolioarbejdet har medvirket til, at de studerende er blevet mere bevidste om fagets relevans samtidig med, at det har hjulpet dem til at bevare fokus undervisningsforløbet igennem. Det har endvidere været med til at give de studerende et overblik over faget, og hjulpet dem til at se nogle sammenhænge mellem fagets forskellige elementer, som ellers kunne have været svære for dem at få øje på. Det er undervisers oplevelse, at e-portfolioarbejdet har motiveret de studerende i deres arbejde med faget, understøttet dybdelæring og bidraget til øget læringsudbytte.

\section{En e-portfoliomodel for relevans og sammenhæng}

Smith \& Tillema (2003) hævder, at "[t]he same type of portfolio cannot be used for assessment and professional development purposes" (s. 646). Vi kan imidlertid ud fra undersøgelsen af TAS I-forløbet konkludere, at den obligatoriske uddannelsesportfolio fungerer som en vej ind i den personlige udviklingsportfolio for den enkelte studerende. Undervejs i semestret, hvor studerende udarbejder portfoliopgaver, deler e-portfolioen med underviser og medstuderende samt reflekterer over udvælgelse af indhold og indholdet selv, danner de sig et overblik over og finder den røde tråd mellem fagets elementer. For at understøtte de studerende i at skabe sammenhæng mellem fagene i en uddannelse og mellem uddannelsen og fremtidigt job er vores forslag at implementere ugentlige refleksionsøvelser, der skal hjælpe den studerende til at udarbejde sin personlige udviklingsportfolio ved at kigge på tværs af elementerne i det enkelte fag, men også på tværs af fag i uddannelsen og fra uddannelsen til fremtidigt job jf. figur 8 nedenfor. Ift. den ovenfor beskrevne TAS I e-portfoliomodel, er det således det personlige udviklingsperspektiv, der skal styrkes. Vores bud på en e-portfoliomodel, der kan understøtte studerende i at se relevans og sammenhænge og dermed styrke motivation og engagement vil dermed se ud som følger. 


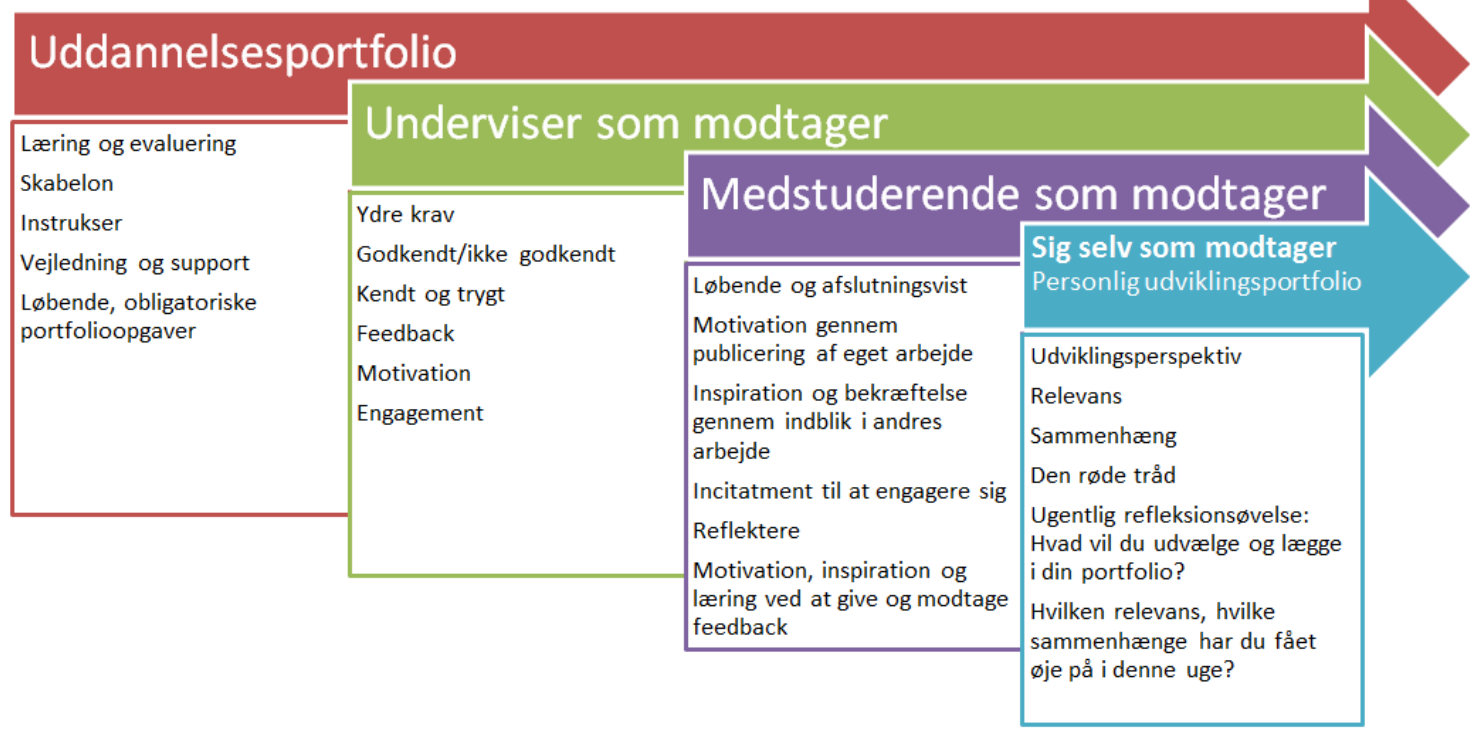

Figur 8. Portfoliomodel for relevans og sammenhæng.

Undersøgelsen af TAS I-forløbet har vist, at underviseren spiller en central rolle ift. at facilitere et e-portfolioforløb på 1. semester af en bacheloruddannelse. Nedenfor er formuleret et sæt retningslinjer til undervisere, der konkretiserer, hvordan du kan støtte og guide de studerende.

\section{Sådan understøtter du portfolioforløb for førsteårsstuderende}

- Udarbejd en manual til de studerende med de vigtigste informationer om brug af e-portfolioværktøjet.

- Udarbejd tydelige e-portfolioguidelines til de studerende, herunder en portfolioskabelon.

- Tydeliggør, at e-portfolioen er et værktøj til at samle og dele opgaver.

- Afsæt en undervisningslektion til trin for trin at vise de studerende, hvordan de opretter, tilgår og deler e-portfolioen. Den første e-portfolioopgave kan med fordel igangsættes i forlængelse af dette, så de studerende begynder e-portfolioarbejdet i trygge rammer - med mulighed for at stille spørgsmål og få hjælp til de første begyndervanskeligheder.

- Lav mange mindre portfolioopgaver semestret igennem, der omhandler forskellige vigtige dele af pensum. Vær sikker på, at de studerende har mulighed for at udarbejde det ønskede materiale til e-portfolioen.

- Læg op til, at mindst én af opgaverne skal indeholde andet multimedieindhold end tekst ( $\mathrm{fx}$ lyd eller video).

- Sørg for, at det fremgår af opgaveformuleringen, hvornår og hvordan den studerende skal aflevere sin e-portfolio.

- Angiv, hvornår e-portfolioen skal deles og med hvem. Vær opmærksom på, om de studerende skal/må se hinandens opgaveløsninger før 
eller efter afleveringsfristen. Det vil afhænge af opgavetype. Ved opgaver med én korrekt løsning vil det fx ikke være hensigtsmæssigt, at de studerende ser hinandens opgaveløsning før aflevering, hvorimod det ved fx wiki-artikler, hvor alle skriver om hvert deres begreb, giver god mening, at de studerende løbende kan følge hinandens arbejde (evt. give/modtage feedback) for inspiration og øgede læringsmuligheder.

- Lav en refleksionsøvelse fx hver uge, hvor de studerende gennemgår deres arbejde og reflekterer over, hvad der skal lægges i e-portfolioen, hvad der skal videreudvikles osv.

- For at afrunde portfolioforløbet kan man ved forløbets afslutning lade de studerende præsentere deres e-portfolioer for hinanden, mens de bl.a. fortæller om hvilke refleksioner, de har gjort sig undervejs.

- Hvis den studerendes e-portfolio indgår i bedømmelsen, er det vigtigt, at underviser er eksplicit omkring bedømmelseskriterierne. Bedømmelseskriterierne vil påvirke, hvad de studerende lægger i deres eportfolio - fx hvor kreative og udforskende de "tør" være.

\section{Konklusion og perspektivering}

E-portfolioen har et stort potentiale ift. den studerendes dokumentation og organisering af arbejde og aktiviteter i løbet af et kursus. Den understøtter en dybdelæringstilgang og styrker de studerendes læringudbytte, idet de kurset igennem kan følge deres egen læringsrejse og kontinuerligt bliver mindet om, hvilke opgaver, de har løst. De studerende oplever, at portfolioen giver overblik, og fungerer som en rød tråd i undervisningen, men de nævner også, at denne erkendelse først sker hen mod slutningen af forløbet. Dette overblik er formodentligt ikke noget, underviseren kan give indledningsvist. Den studerende skal selv arbejde sig frem til det over tid, da "development of knowledge and understanding usually take some time to be recognised" (Dysthe \& Engelsen, 2011, s. 75). Processen kan måske lettes ved at give de studerende eksempler på portfolioer fra tidligere år samt kontinuerligt bede dem reflektere over deres eget læringsudbytte, og hvad der vil være relevant at lægge i deres portfolio. Underviseren spiller en afgørende rolle ift. at støtte og guide de studerende via opmuntring, tydelige krav og retningslinjer samt vejledning og support ift. portfolioværktøjet.

De studerende føler sig mest trygge ved portfolioen, når den anvendes som en obligatorisk uddannelsesportfolio med underviseren som den konkrete modtager, og hvor underviseren specifikt angiver, hvad der skal lægges i den. De har sværere ved at forstå det personlige udviklingsperspektiv, og at de også har mulighed for selv at udvælge eksempler på deres arbejde, som de kan lægge i portfolioen, samt at de kan anvende den til selvevaluering og refleksion over deres personlige og faglige udvikling, dvs. identitetsopbygning inden for fagfeltet, hvilket kan medvirke til at skabe relevans og se 
sammenhænge mellem uddannelsen og det job, de skal ud at varetage efter endt uddannelse. Et vigtigt opmærksomhedspunkt bør derfor være, hvordan dette læringselement kan styrkes i det enkelt fag, på tværs af fag i uddannelsen samt på tværs af uddannelsen og fremtidigt job? Her bør de studerende støttes $\mathrm{i}$ at se sig selv som modtager af portfolioen gennem $\mathrm{fx}$ refleksionsøvelser.

I TAS I-forløbet blev der fokuseret på let adgang, mulighed for multimedieindhold, samling og organisering af opgaver, noter og refleksioner, deling med underviser og medstuderende samt feedback, hvorfor e-portfolioværktøjet i Blackboard, SDU's e-læringsplatform blev valgt. Imidlertid er konklusionen, at en del studerende har brug for teknisk support udover den tilgængelige manual, at feedback funktionen er for begrænset idet feedback ikke kan knyttes til individuelt indhold eller filer, som der fx er mulighed for i e-portfoliosystemet Mahara (Ugolini \& Orazi, 2015), samt at de studerende skal støttes i at anvende multimedieindhold. Der er desuden $\emptyset n s k e$ om, at man kan dele portfolioen permanent og ikke blot som snapshot, der skal fjernes og et nyt sendes, når der er foretaget ændringer. Dog viser interviewundersøgelsen også, at de studerende foretrækker at anvende et e-portfolioværktøj i den eksisterende e-læringsplatform snarere end at skulle anvende et helt nyt system.

Det må konstateres, at portfolio som lærings-, udviklings- og evalueringsredskab samt e-portfolioen er nye og uvante koncepter. Ift. læring og evaluering er det de enkelte portfolioopgaver, der får fokus og opmærksomhed. Ift. digitaliseringen er det den velkendte skriftlige fremstilling, de studerende falder tilbage på. De har ikke blik for de muligheder, som den digitale portfolio giver ift. at arbejde med multimedieindhold. Førstnævnte vil kunne håndteres ved, at de studerende fremover skriver opgaver direkte ind i portfolioen, hvorefter de afleverer portfolioen til bedømmelse. Sidstnævnte kan søges understøttet via portfolioopgaver, der angiver obligatorisk multimedieindhold, dvs. at en opgave skal afleveres som et produkt med fx lyd og/eller video.

Indledningsvist motiveres de studerende af det obligatoriske aspekt, men det bliver senere en motivationsfaktor, at medstuderende kan kigge med og kommentere, og at der således er et publikum til den voksende portfolio. De studerende har engageret sig i e-portfolioforløbet i forskellig grad, der afspejler deres engagement i den øvrige undervisning. Der er således ikke belæg for at konkludere at e-portfolio er en metode, der kan engagere den gruppe af studerende, der generelt er svær at nå. Der er indikationer på, at krav om anvendelse af multimedieindhold kan motivere studerende, hvilket understreger vigtigheden af at inkludere denne komponent i et eportfolioforløb. 
Før man som underviser kaster sig ud i e-portfolioarbejde, skal man være indstillet på, at der kan være en stor arbejdsbyrde forbundet med det. Det er tidskrævende at gennemgå, kommentere og bedømme mange studerendes e-portfolioer op til flere gange i løbet af et undervisningsforløb. Dog har det den fordel, at man får et godt overblik over hver enkelt studerendes arbejde.

\section{Referencer}

Baeten, M., Kyndt, E., Struyven, K., \& Dochy, F. (2010). Using studentcentred learning environments to stimulate deep approaches to learning: Factors encouraging or discouraging their effectiveness. Educational Research Review, 5(3), 243-260. doi:10.1016/j.edurev.2010.06.001

Briggs, A. R. J., Clark, J., \& Hall, I. (2012). Building bridges: understanding student transition to university. Quality in Higher Education, 18(1), 3-21. doi:10.1080/13538322.2011.614468

Chen, B., Seilhamer, R., Bennet, L. and Bauer, S. (2015). Students' Mobile Learning Practices in Higher Education: A Multi-Year Study. Educause Review, June 22, 2015.

Donnison, S., \& Penn-Edwards, S. (2012). Focusing on first year assessment: surface or deep approaches to learning? The International Journal of the First Year in Higher Education, 3(2), 9. doi:10.5204/intjfyhe.v3i2.127

Driessen, E. W., Muijtjens, A. M. M., Tartwijk, J. v., \& Vleuten, C. P. M. v. d. (2007). Web- or paper-based portfolios: is there a difference? Medical Education 2007, 41, 1067-1073.

Dysthe, O. \& Engelsen, K. S. (2011). Portfolio practices in higher education in Norway in an international perspective: macro-, meso- and microlevel influences. Assessment \& Evaluation in Higher Education, Vol. 36, No. 1, January 2011, 63-79.

Englund, C., Olofsson, A. D., \& Price, L. (2016). Teaching with technology in higher education: understanding conceptual change and development in practice. Higher Education Research \& Development, 36(1), 73-87. doi:10.1080/07294360.2016.1171300

Entwistle, N. (2009). Teaching for understanding at university: Deep Approaches and Distinctive Ways of Thinking. London: Palgrave Macmillan.

Eynon, B., Gambino, L. M., \& Török, J. (2014). Completion, Quality, and Change: The Difference E-Portfolios Make. Peer Review, 16(1), Winter 2014, 8-18. 
Frederiksen, M. (2013). Integration I 'mixed methods' forskning: Metode eller design. IN Metode \& Forskningsdesign. Nr. 1, 2013, 17-40.

Güzeller, C. O. (2012). The effect of web-based portfolio use on academic achievement and retention. Asia Pacific Education Review, 2012, 13, 457464.

Henderson, M., Selwyn, N., Finger, G., \& Aston, R. (2015). Students' everyday engagement with digital technology in university: exploring patterns of use and 'usefulness'. Journal of Higher Education Policy and Management, 37(3), 308-319. doi:10.1080/1360080x.2015.1034424

Johannsen, B. F, Ulriksen, L. \& Holmegaard, H. T. (2013). 3.1. Deltagerforudsætninger I: Rienecker, L., Jørgensen, P. S., Dolin, J. \& Ingerslev, G. H. (red.) (2013). Universitetspædagogik. Frederiksaberg C: Samfundslitteratur.

Johnson, B. \& Christensen, L. (2012). Educational Research: Quantitative, Qualitative, and Mixed Approaches. 4. udgave. SAGE Publications.

Johnson, L., Adams Becker, S., Cummins, M., Estrada, V., Freeman, A., and Hall, C. (2016). NMC Horizon Report: 2016. Higher Education Edition. Austin, Texas: The New Media Consortium.

Kvale, S. \& Brinkmann, S. (2015). Interview: Det Kvalitative Forskningsinterview som Håndværk. 3. udgave. Hans Reitzels Forlag.

Lund, B. (red.) (2008). Portfolio i et lærings- og uddannelsesperspektiv. Aalborg: Aalborg Universitetsforlag.

Means, T. B., Jonassen, D. H., \& Dwyer, F. M. (1997). Enhancing relevance: Embedded ARCS strategies vs. purpose. Educational Technology Research and Development, 45(1), 5-17.

Mohamad, S. N. A., Embi, M. A., \& Nordin, N. M. (2016). Designing an EPortfolio as a Storage, Workspace and Showcase for Social Sciences and Humanities in Higher Education Institutions (HEIs). Asian Social Science, 12(5), 2016, 185-194.

Moon, J. (2004). A Handbook of Reflective and Experiential Learning. London: Routledge Falmer.

Morgan, D. L. (1998). Practical strategies for combining qualitative and quantitative methods: Applications to health research. Qualitative Health Research 8, 362-376.

Paulson, F. L, Paulson, P. R \& Meyer, C. A. (1991). What Makes a Portfolio a Portfolio? Educational Leadership, February 1991, Volume 48, Issue 5, 60-63. 
Popescu-Mitroia, M., Todorescu, L., Greculescu, A. (2015). The Usefulness of Portfolios as Assessment Tools in Higher Education. Procedia - Social and Behavioral Sciences 191 (2015), 2645 - 2649.

Price, L., \& Kirkwood, A. (2013). Using technology for teaching and learning in higher education: a critical review of the role of evidence in informing practice. Higher Education Research \& Development, 33(3), 549-564. doi:10.1080/07294360.2013.841643

Selwyn, N. (2016). Digital downsides: exploring university students' negative engagements with digital technology. Teaching in Higher Education, 21(8), 1006-1021. doi:10.1080/13562517.2016.1213229

Smith, E., \& Mills, J. (2009). E-portfolios and first year students - do we assume too much? Paper presented at the 20th Annual Conference for the Australasian Association for Engineering Education, 6-9 December 2009: Engineering the Curriculum. Barton, A.C.T.: Engineers Australia, 2009, 400-404.

Smith, K. \& Tillema, H. (2003). Clarifying Different Types of Portfolio Use. Assessment \& Evaluation in Higher Education, Vol. 28, No. 6, December 2003, 625-648.

Struyven, K., Dochy, F., Janssens, S., \& Gielen, S. (2006). On the dynamics of students' approaches to learning: The effects of the teaching/learning environment. Learning and Instruction, 16(4), 279-294. doi:10.1016/j.learninstruc.2006.07.001

Studieordningen for BA i Audiologi og for BA i Logopædi (2015). Det Humanistiske Fakultet. Syddansk Universitet.

Trigwell, K., \& Prosser, M. (1991). Improving the quality of student learning: the influence of learning context and student approaches to learning on learning outcomes. Higher Education, 22(3), 251-266.

Ugolini, F. C. \& Orazi, R. (2015). Constructing an e-portfolio of competences with higher education students of postsecondary age group. Technological issues and outcomes. Research on Education and Media. Volume 7, Issue 1, 2015.

Wingate, U. (2007). A Framework for Transition: Supporting 'Learning to Learn' in Higher Education. Higher Education Quarterly, 61(3), 391-405. doi:10.1111/j.1468-2273.2007.00361.x

Woodward, H. \& Nanlohy, P. (2004). Digital portfolios: fact or fashion? Assessment \& Evaluation in Higher Education. Vol. 29, No. 2, April 2004, 227-238. 
Yancey, K. B. (1998). Reflection in the writing classroom. Logan, UT: Utah State University Press.

Yorke, M. (2006). Student engagement: Deep, surface or strategic. Paper presented at the Keynote address to the 9th Pacific Rim Conference on the First Year in Higher Education, Griffith University, Australia.

Zepke, N. (2015). Student engagement research: thinking beyond the mainstream. Higher Education Research \& Development, 34(6), 13111323.

\section{Bilag 1. Spørgeskema}

\section{Spørgeskema vedr. brug af e-portfolio i Teoretisk og Anvendt Sprogvidenskab I - Morfologi og Syntaks (TAS I)}

Som studerende kan det være en udfordring at se sammenhængen mellem: 1) et fags enkelte dele; 2) en uddannelses forskellige fag; og 3) enkelte fag på uddannelsen og det arbejde, som den studerende skal ud og varetage efter endt uddannelse. I TAS I har vi arbejdet med e-portfolio med henblik på at imødekomme denne udfordring og skabe mål, motivation og fokus i undervisningen.

Jeg håber, at I vil besvare nedenstående spørgeskema med henblik på at undersøge i hvor høj grad dette er lykkedes, og hvordan det kan forbedres fremover.

\section{I hvor høj grad har arbejdet med e-portfolioen medvirket til at:}

$\begin{array}{ccrcr}\text { I meget } & \text { I høj } & \text { I nogen } & \text { I lav } & \text { Slet } \\ \text { høj } & \text { grad } & \text { grad } & \text { grad } & \text { ikke } \\ \text { grad } & & & & \end{array}$

\begin{tabular}{|c|c|c|c|c|c|}
\hline $\begin{array}{l}\text { du har sat konkrete mål } \\
\text { for din egen læring? }\end{array}$ & (1) & (2) & (3) & (4) & (5) \\
\hline $\begin{array}{l}\text { motivere dig i } \\
\text { undervisningen? }\end{array}$ & $(1 \mathrm{q}$ & (2) & (3) & (4) & (5) \\
\hline $\begin{array}{l}\text { gøre din læring mere } \\
\text { fokuseret? }\end{array}$ & (1) & (2) & (3) & (4) & (5) \\
\hline
\end{tabular}

Uddyb - her kan du skrive kommentarer til de svar du gav i spørgsmålet ovenfor 
I hvor høj grad har arbejdet med e-portfolioen bidraget til at skabe sammenhæng mellem fagets (TAS I) forskellige elementer?
(1) I meget høj grad
(2) I høj grad
(3) I nogen grad
(4) I lav grad
(5) Slet ikke

I hvor høj grad har arbejdet med e-portfolioen bidraget til at skabe sammenhæng mellem TAS I og andre fag på uddannelsen?
(1) I meget høj grad
(2) I høj grad
(3) I nogen grad
(4) I lav grad
(5) Slet ikke

I hvor høj grad har arbejdet med e-portfolioen bidraget til at skabe sammenhæng mellem TAS I og det arbejde, som du skal ud og varetage efter endt uddannelse?
(1) I meget høj grad
(2) I høj grad
(3) I nogen grad
(4) I lav grad
(5) Slet ikke

Fortæl kort hvad har du fået ud af at arbejde med de forskellige elementer af e-portfolioen?

Portræt

Mål

Begreber

Morfologisk analyse

Syntaktisk analyse

Sprogblomster

Hvad fungerede godt?

Hvad fungerede mindre godt?

Har du forslag til forbedringer?

Du er nu færdig med at udfylde spørgeskemaet. Tusind tak for din hjælp. 


\section{Bilag 2. Interviewguide}

1. Hvad forstår du ved en e-portfolio?

2. Hvem ser du som modtager af e-portfolioen?

3. Hvordan har du arbejdet med e-portfolioen i TAS I?

4. Har du følt dig engageret i arbejdet med e-portfolioen?

a. Hvad kunne have fået dig til at engagere dig i endnu højere grad?

b. Hvad kan man gøre for at få flere studerende til at engagere sig mere i arbejdet med e-portfolioen?

5. Vælg de tre kort, der bedst beskriver din oplevelse af at arbejde med eportfolioen: (motivation - rød tråd - overblik - sekundært - fokus ekstra arbejde - kompliceret (teknisk) - forvirrende - spild af tid (andet) - ?

a. Vil du uddybe det? Vil du fortælle mere om det?

6. Hvordan oplevede du, at arbejdet med e-portfolioen styrkede sammenhængen mellem de forskellige elementer af TAS I?

a. Hvordan kunne man ved hjælp af e-portfolioen (i endnu højere grad) styrke denne sammenhæng?

7. Hvordan oplevede du, at arbejdet med e-portfolioen styrkede sammenhængen mellem TAS I og de øvrige fag på uddannelsen?

a. Hvordan kunne man ved hjælp af e-portfolioen (i endnu højere grad) styrke denne sammenhæng?

8. Hvordan oplevede du, at arbejdet med e-portfolioen styrkede sammenhængen mellem studiet og det arbejde, som du skal ud at varetage efter endt uddannelse?

a. Hvordan kunne man ved hjælp af e-portfolioen (i endnu højere grad) styrke denne sammenhæng?

9. Har du brugt forskelligt multimedieindhold i din e-portfolio ( $\mathrm{fx}$ billeder, lyd og video)?

a. Hvorfor? / Hvorfor ikke?

b. Hvad kunne have fået dig til i højere grad at bruge forskelligt multimedieindhold?

c. Hvordan kunne man få de studerende til i endnu højere grad at udnytte e-portfolioens muligheder for brug af forskelligt multimedieindhold, fx mht. billeder, lyd, video?

10. Hvordan oplevede du det tekniske med hensyn til at lave e-portfolioen og dele den?

a. Har du forslag til, hvad der kunne gøre det nemmere?

b. Har du forslag til andre systemer/andet software, der kan bruges i stedet for?

11. Har du mere du gerne vil tilføje? 


\section{Bilag 3. TAS I e-portfolioen - instrukser til de studerende}

\section{Portræt}

Instruks: Du skal her arbejde med at skabe din egen faglige profil - dit faglige visitkort. Det kan du gøre ved hjælp af fx tekst, billeder, lyd og/eller video. Du kan fx indføje oplysninger som din uddannelsesmæssig baggrund, relevant erhvervserfaring, faglige interesser eller andet som du finder relevant. Det er op til dig hvordan du ønsker at gøre det, men du skal som minimum indsætte et billede af dig selv - det hjælper mig til at lære jer alle at kende. Du vil have mulighed for at redigere og udbygge din profil $\mathrm{i}$ løbet af semestret.

\section{Mål}

Instruks: Du skal her arbejde med målene for faget TAS I. For at løse denne opgave er det en god idé at du sætter dig grundigt ind i hvad studieordning og fagbeskrivelse siger om faget. Det er også vigtigt at du undersøger og selv reflekterer over hvad det er ved faget der er vigtigt for resten af din uddannelse og dit senere arbejde - og hvorfor det er vigtigt. Reflektér over hvad der er dine styrker og svagheder, og hvor det derfor er vigtigt at du lægger en særlig stor arbejdsindsats.

\section{Begreber}

Instruks: Du skal her uploade den wiki-artikel, som du har ansvaret for. Jeg vil desuden opfordre dig til at samle dine noter til faget her så de er let tilgængelige for dig semestret igennem (og i resten af din studietid).

\section{Morfologisk analyse}

Instruks: Her uploader du dine morfologiske afleveringsopgaver mv.

\section{Syntaktisk analyse}

Instruks: Her uploader du dine syntaktiske afleveringsopgaver, inkl. feedback til/fra din medstuderende mv.

\section{Sprogblomster}

Instruks: Jeg vil opfordre dig til at være opmærksom på sproget i dine omgivelser og indsamle sprogblomster som du støder på i din hverdag. Det kan både være i form af avisudklip, lydklip, transskriberet tale, videooptagelse af tv-udsendelse eller lign. Upload dem her. Nogle af eksemplerne vil vi tage op og arbejde med i undervisningen. 


\section{Bilag 4. Eksempler på studenterportfolioer}

\section{Eksempel 1}

Se hele portfolioen her:https://e-learn.sdu.dk/bbcswebdav/xid-74288931

\section{Teoretisk og Anvendt Sprogvidenskab I}

Portræt Mål Morfologisk analyse Begreber Syntaktisk analyse Sprogblomster

\section{Mål}

\section{Mål for TAS I}

At have et mål og gerne flere mål er vigtigt for mig. Det er en måde, hvorpå jeg kan blive involveret $\mathrm{i}$ et emne eller et fag og blive god til det. Derfor har jeg også sat nogle mål for faget TAS I, både de beskrevne mål i studieordningen og min egne mål.

Jeg har læst og forstået Studieordningen Bacheloruddannelsen Logopædi 2015 rev. 2016, herunder beskrivelsen af faget TAS I. Målet for TAS I er, at jeg skal kunne vise min viden om sprogvidenskabens teoretiske og anvendte sprogdiscipliner. Jeg skal også kunne udføre sprogvidenskabelige analyser af typisk og atypisk sprog. Derudover står der skrevet i studieordningen, at jeg, som en færdighed, skal kunne foretage morfologiske og syntaktiske analyser af dansk sprog. Derfor skal jeg som en kompentence kunne bestemme og redegøre for morfologi og syntaks i atypisk og typisk brug i danske eksempler* At skulle lære disse førnævnte færdigheder og kompetencer kommer til at give mig en dybere forståelse af, hvad sprogvidenskab er. Det er vigtigt at lære at om morfologi og syntaks, fordi de er væsentlige grundelementer for sproget.

At sætte sig mål handler også om at finde sine egne styrker og svagheder og være opmærksom på dem. En styrke for mig er, at jeg godt kan lide grammatik og sprog. Det interesser mig, og jeg føler, at jeg har nogle gode færdigheder med fra mit arbejde i dansk og tysk. En anden styrke hos mig er, at jeg er struktureret og har meget selvdisciplin. Det er vigtigt, når der er meget stof og mange begreber at lære og holde styr på. Med styrker følger der også svagheder. Jeg har blandt andet den svaghed, at jeg hurtigt kan blive frustreret på mig selv, hvis jeg ikke kan finde ud af at løse en opgave første gang. Et personligt mål for mig er at blive bedre til at have tålmodighed og huske mig selv på, at det handler om en proces, hvor jeg kommer til at lave fejl, for at kunne nå i mål. En anden svaghed hos mig er, at jeg hurtig kan stresse mig selv. Et andet personligt mål er derfor at blive bedre til at bevare roen, hvis der kommer mange opgaver og nye informationer på samme tid.

Jeg har sat mig selv for, at jeg vil nå de mål, der står beskrevet i studieordningen og mine egne personlige mål. Det er vigtigt at opfylde målene og blive gode til dem, fordi det er et godt grundlag at have med videre i uddannelsen og videre ud i et fremtidigt job. Allerede i næste semester vil der komme andre TAS-fag og her vil det være oplagt at kunne trække på noget af det, som vi har lært i TAS I. Eksempelvis skal vi i TAS I kunne lave sprogvidenskabelige analyser af typisk så vel som atypisk sprog, hvilket også er gældende for TAS II, III så vel som IV. I et fremtidigt job, som logopæd, er viden om sproget, dets opbygning og begreber en væsentlig del af at eksempelvis kunne hjælpe et andet menneske med at tilegne sig sproget igen.

At nå succesfuldt i mål og føle sig sikker i den tillærte viden fra TAS I, kommer ikke af sig selv. Det er vigtig at tillægge sig selv en stor arbejdsindsats, fordi det er den eneste måde, hvorpå jeg virkelig kan blive god til morforlogi og syntaks. Det handler om, at jeg skal øve mig mange gange på at lave sprogvidenskabelige analyser af morfologiske og syntaktiske analyser. Derudover handler det om, at jeg skal øve mig mange gange på begreber og grundprincipper inden for morfologi og syntaks. Ikke mindst skal jeg også øve mig på de andre opgaver, der vil blive stillet. Jeg vil være sikker i det, som jeg lærer i TAS I, fordi jeg skal kunne bruge denne viden til at hjælpe andre mennesker.

Eksempel på studerendes e-portfolio fra TAS I-forløbet. 


\section{Eksempel 2}

Se hele portfolioen her:https://e-learn.sdu.dk/bbcswebdav/xid-7429567 1

\section{Teoretisk og Anvendt Sprogvidenskab I}

Portræt Mål Morfologisk analyse Begreber Syntaktisk analyse Sprogblomster

\section{Mål}

\section{Mål for TAS I}

Fagene i TAS I dækker over morfologi (orddannelse/ordbøjning) og syntaks (sætningsdannelse). Umiddelbart ikke fag, som forbindes med hørelsen og hørenedsættelse. At der ingen sammenhæng er, er dog en forkert antagelse.

Som audiologistuderende på TAS I skal jeg have en grundlæggende viden (begreber/principper) om morfologi og syntask. Især hos børn er hørelsen væsentlig for indlæring - ikke kun vedr. talen, men i de fleste sammenhænge. Derfor vil viden om sprogets grundsten give viden omkring hvilke processer der fungerer mindre godt hos en patient.

Af samme grund er det vigtigt at kunne skelne mellem sprog i tale og må skrift, da der her er forskelle. Specielt fokus må naturligvis være på dansk, da dette er vores primære arbejdsområde.

Da viden ikke er alt, vil det også være nødvendigt at kunne foretage analyser (morfologiske og syntaktiske) af det danske sprog, da vi ellers vil være på bar bund i klinikken. For at kunne analysere og fejlfinde de naturlige og konventionelle processer, vil vi også skulle lære at identificere og redegøre for både typisk og atypisk brug af sproget.

For mig personligt vil der være fokus på min dysleksi, da jeg har en tendens til at blande rundt i bogstaver og ord.

Eksempel på studerendes e-portfolio fra TAS I-forløbet. 


\section{Bilag 5. Indhold og intentioner med TAS I portfolioens forskellige sider}

TAS I-portfolioen indeholdt følgende elementer, der hver udgjorde en side i skabelonen:
1) Portræt
2) Mål
3) Begreber
4) Morfologisk Analyse
5) Syntaktisk Analyse
6) Sprogblomster

På siden Portræt skulle de studerende udarbejde et fagligt visitkort. Der var valgfrihed mht. udarbejdelse af portrættet, der som minimum skulle indeholde et billede af de studerende. Formålet var at få de studerende til at reflektere over og begynde at skabe deres egen faglige profil. Under Mål skulle de studerende arbejde med målene for faget med det formål at få dem til at sætte sig grundigt ind i studieordning, fagbeskrivelse og undervisningsplan, samt at sætte sig ind $i$, hvad det var ved faget, der var vigtigt for resten af deres uddannelse og fremtidige job - og ikke mindst hvorfor. Derudover skulle de reflektere over, hvad de personligt ønskede at få ud af undervisningen, samt hvad de anså som deres styrker og svagheder. Opgaven tog udgangspunkt i en forventning om, at: a) det ville være en motivationsfaktor i sig selv, at de studerende var bevidste om formålet med faget og dets enkelte elementer; og b) det ville hjælpe de studerende til at bevare fokus i undervisningen. Denne del af e-portfolioen udgjorde således en forventningsafstemning, som skulle være central ift. at motivere de studerende i undervisningen samt understøtte en dybdelæringstilgang.

På siden Begreber skulle de studerende uploade en wiki-artikel, som de hver især havde ansvaret for at udarbejde i løbet af semestret. De studerende skulle ved hjælp af wiki-værktøjet i Blackboard samarbejde om at udvikle en fælles begrebsdatabase om sprogvidenskabelige begreber med fokus på morfologi og syntaks, som de kunne have gavn af gennem hele deres studie. Hver studerende fik ved semesterstart udleveret et begreb som vedkommende havde ansvaret for at skrive en wiki-artikel om. De studerende skulle læse de andres wiki-artikler, give kritik og bidrage med alternative forklaringer, udvidelser og forbedringer. De endelige wikiartikler skulle til sidst uploades i den studerendes e-portfolio.

Formålene med denne opgave var at facilitere de studerendes oparbejdelse af en dyb viden om et begreb, der var nøje udvalgt på baggrund af fagets pensum (ved at sætte sig så grundigt ind i et begreb, at de kunne formidle 
det til andre). De studerende ville samtidig opnå en bred viden ved at læse de andre wiki-artikler så grundigt, at de kunne give konstruktiv kritik på disse. Kombinationen af dyb og mere bred viden skulle styrke de studerendes læringsudbytte. Antagelsen var, at det ville motivere de studerende, at de var fælles om at skabe et produkt (wiki-begrebsdatabasen), men samtidig også, at de ville føle et personligt ansvar for én wikiartikel. Der var en forventning om, at de studerende ville blive bedre til at formulere sig om faglige emner ved at skrive deres egne wiki-artikler og ved at give kritik på andres. Der var endvidere en forventning om, at samarbejdet om at udvikle denne begrebsdatabase, ville styrke de studerendes samarbejdsevner, samt at øvelsen i at give og modtage feedback ligeledes ville opøve evnen til at give og modtage kritik hos de studerende. Både formuleringsevne, samarbejdsevner og evnen til at give og modtage kritik er vigtig for de studerende i deres fremtidige job. På denne side havde de studerende endvidere mulighed for at samle noter fra faget, så disse var let tilgængelige uddannelsen igennem.

På siderne Morfologisk Analyse og Syntaktisk Analyse skulle de studerende uploade henholdsvis deres morfologiske og syntaktiske afleveringsopgaver, inkl. feedback til/fra medstuderende. Her var formålet at give den studerende mulighed for at øve sig i at lave analyser. Ved at gøre det til en aflevering havde underviseren mulighed for at vurdere den enkelte studerendes kompetencer inden for dette felt. At afleveringsopgaverne opbevares ét sted sammen med fagets øvrige noter, skulle bidrage til øget overblik.

Endelig var der siden Sprogblomster. Her opfordrede underviseren de studerende til at være opmærksomme på sproget i deres omgivelser og indsamle og uploade sprogblomster, som de stødte på i deres hverdag. En sprogblomst er et ord eller et udtryk, der skiller sig ud fra det neutrale sprog ved at være særligt elegant, groft eller upassende eller ved at være fejlagtigt på en morsom måde (sproget.dk). Nogle af eksemplerne blev inddraget i selve undervisningen. Formålet var at gøre de studerende opmærksomme på vigtigheden af grammatik og at inspirere de studerende til at øge opmærksomheden på det sprog, der omgav dem - dette med henblik på at understøtte de studerendes udvikling af sproglig bevidsthed. Der var endvidere en formodning om, at de studerende ville finde undervisningen mere vedrørende og relevant, når den tog udgangspunkt i deres egne eksempler, og sjovere, når der blev inddraget eksempler, hvor sproget fx var (ufrivilligt) morsomt pga. særlige (fx tvetydige) konstruktioner. 